\title{
OPEN Evaluation of quasi-static and dynamic nanomechanical properties of bone-metastatic breast cancer cells using a nanoclay cancer testbed
}

\begin{abstract}
Sumanta Kar, Dinesh R. Katti \& Kalpana S. Katti ${ }^{\bowtie}$
In recent years, there has been increasing interest in investigating the mechanical properties of individual cells to delineate disease mechanisms. Reorganization of cytoskeleton facilitates the colonization of metastatic breast cancer at bone marrow space, leading to bone metastasis. Here, we report evaluation of mechanical properties of two breast cancer cells with different metastatic ability at the site of bone metastases, using quasi-static and dynamic nanoindentation methods. Our results showed that the significant reduction in elastic modulus along with increased liquid-like behavior of bone metastasized MCF-7 cells was induced by depolymerization and reorganization of F-actin to the adherens junctions, whereas bone metastasized MDA-MB-231 cells showed insignificant changes in elastic modulus and $\mathrm{F}$-actin reorganization over time, compared to their respective as-received counterparts. Taken together, our data demonstrate evolution of breast cancer cell mechanics at bone metastases.
\end{abstract}

With the advent of novel experimental and modeling methodologies, there has been an increasing interest in investigating the mechanical properties of individual cells to delineate disease mechanisms ${ }^{1,2}$. Increasing evidence supports that altered mechanical properties influence cancer pathogenesis and progression at the cellular level ${ }^{3}$. Several studies have compared the stiffness of cancer cells as compared to their healthy counterparts ${ }^{4-12}$.

The epithelial monolayer, a multicellular system composed of firmly connected adjacent cells via adherens junctions, substantially impacts the progression of many human cancers ${ }^{13}$. The actin cytoskeleton of healthy epithelial cells is attached to adherens junctions to counteract internal and external mechanical stimuli and bestow mechanical stability ${ }^{14}$. In contrast, cancerous epithelial cells most often exhibit disruption in stable cell-cell adhesion due to alterations in either adherens junctions or actin cytoskeleton ${ }^{15-17}$. A few studies have also compared the distribution/expression of the actin cytoskeleton in breast cancer cells with normal breast cells using fluorescence staining/western blot and observed impaired stress fiber formation/reduced levels of F-actin expression in breast cancer cells as compared to normal breast cells, $, 9,18-20$.

Various methods are used to measure mechanical properties of cells, including atomic force microscopy $(\mathrm{AFM})^{7,8,18,19,21-35}$ and direct nanoindentation ${ }^{36,37}$. Intrinsic differences exist between the various mechanobiological experiments conducted in the context of geometry of indentor, its penetration as well as engagement of varying volumes of the cell. AFM based studies are based on cantilever mounted probes that evaluate mechanics of cellular systems based on their approach and retraction of the probes. Several AFM-based reports in the literature report elastic moduli of cancer cells in comparison to their healthy counterparts ${ }^{6-10,38,39}$. A recent AFM study evaluates the important connections between energy metabolism and cell stiffness in breast cancer cells comparing healthy cells and metastatic breast cancer cells ${ }^{40}$ Unique metabolic adaptations of cancer cells in comparison to healthy cells are well known ${ }^{41}$. AFM based microrheology experiments demonstrate use of loss tangent to evaluate malignancy potential of cells ${ }^{38}$. Recent studies also employ the use of AFM in combination with traction force microscopy to evalaute viscoelastic properties as well as and contractile prestress of environment ${ }^{42}$ and development of advanced methodologies with fast force volume and mapping techniques ${ }^{43}$. These newly developed methodologies are highly effective in comparisons of cellular types and characteristics and 
are likely to have important contributions to further understanding of the cell biology of the numerous cancer types. In the development of in silico approaches of the future, accurate values of mechanical properties as well as bevaviour at metastatic sites are needed. The specific values of elastic moduli of cancer cells reported in several AFM based studies are in the kPa range. There are significant differences in the mechanical probing using AFM based methods and direct nanoindentation. The geometry of the AFM tip that is attached to a cantilever has deflections arising from the flexural and rotational stiffness of the cantilever in addition to the material response to applied load while a vertical penetration enabled with a rigid nanoindentor enables a direct measurement of force and displacement. Direct nanoindentation has been applied to measure static and dynamic properties of several biological materials such as osteoblasts ${ }^{44-46}$, tissue engineered bone nodules ${ }^{46}$, soft and mineralized tissues $^{47-52}$, seashells ${ }^{53-55}$, and dental materials ${ }^{56,57}$. The elastic modulus of cell membrane, and cytoplasm are $1.8 \mathrm{kPa}$ and $0.25 \mathrm{kPa}$ respectively ${ }^{58,59}$ while the various cytoskeletal elements such as actin filaments, intermediate filaments, and microtubulkes have elastic moduli of $1 \mathrm{GPa}, 1 \mathrm{GPa}$ and $1.9 \mathrm{GPa}$ respectively ${ }^{60}$. The volume fraction of cytoskeleton in eukaryotic cells is reported to be about $16-21 \%$ of cell volume ${ }^{61}$. Simplistic calculations estimate cellular moduli in the MPa range based on these compositions and properties of constituents. To this end, our group had previously developed a nanoindentation-based technique as an alternative method for measurements of cellular mechanical properties ${ }^{36,45}$

Further, changes to the stiffest component of the cell, actin filaments, can influence modulus of the cell and dysregulation in the actin cytoskeleton can lead to softening in cancer cells ${ }^{3,62-64}$. Actin reorganization and polymerization also results in softening of cancer cells ${ }^{36}$. The overall density and 3D-organization of actin have also been reported to be a dominant factor accounting for the changes in the mechanical response of cancer cells ${ }^{65}$.

Loss of cell-cell adhesion and gain of the invasive mesenchymal phenotype are hallmarks of epithelial-mesenchymal transition (EMT) of cancer cells, a process that promotes cancer cells to invade the basement membrane; a physical barrier made up of their adjacent cells ${ }^{66}$. Upregulation of several actin-cytoskeletal-associated proteins, including myosin light chain, $\alpha$-actinin, integrins, and tropomyosin, has been associated with EMT while reduced expression of pseudopod-enriched proteins including Wiskott-Aldrich syndrome protein (WASP) family members, the actin-related proteins-2/3 (Arp2/3) complex, and cortactin are associated with reversal of EMT or mesenchymal-epithelial transition $(\mathrm{MET})^{16,67-71}$. Moreover, altered expressions of Arp2/3 complex and Wiskott-Aldrich syndrome protein family member 2 (WASP2) have been linked with poor prognosis of breast cancer, indicating a significant role of actin cytoskeleton dynamics in cancer progression ${ }^{72,73}$. Breast cancer is the most prevalent cancer types among women, and it becomes incurable once the disease has metastasized to the bones. Changes in cellular shape and architecture facilitate the colonization of metastatic breast cancer at bone marrow space. Due to the scarcity of accurate and efficient models to replicate cancer progression stages for early detection, most of the patients $(80 \%)$ with breast cancer metastasized to the bones die within five years ${ }^{74}$. Furthermore, studies done to evaluate the changes in breast cancer cells' mechanical properties during cancer progression at the bone-site are lacking, owing to the lack of suitable models to recapitulate the molecular events. In recent years, three-dimensional (3D) culture systems have attracted substantial attention due to their ability to recapitulate in vivo tumor microenvironment by providing adequate spatial and biophysical cues to mimic molecular events during disease progression as compared to two-dimensional (2D) cellular models. Moreover, $3 \mathrm{D}$ culture systems eliminate issues in animal models regarding immunodeficiency, species difference, and uncertain disease pathogenesis ${ }^{75,76}$.

We had earlier reported the development 3D in vitro model for prostate/breast cancer bone metastasis, mimicking MET of breast and prostate cancer in the sequential culture of osteogenically differentiated human mesenchymal stem cells (MSCs) and human prostate/breast cancer cells ${ }^{77,78}$ on nanoclay-based polymer bone mimetic scaffolds ${ }^{79,80}$. The new testbed for bone metastasis also enables evaluation of important signalling pathways during metastasis such as role of $\mathrm{Wnt} / \beta$-catenin signaling on osteogenesis within the bone microenvironment ${ }^{81}$ and drug resistance ${ }^{82}$. Based on static nanoindentation experiments conducted using the testbed approach of metastasis, we also reported that bone-metastatic prostate cancer cells undergoing MET exhibit significant reduction in stiffness due to F-actin reorganization ${ }^{36}$. Based on these observations, we hypothesized that breast cancer cells grown on 3D bone-mimetic scaffolds would exhibit cell mechanics changes over time due to alterations in actin cytoskeleton dynamics and organization during disease progression. To this end, we evaluated mechanical properties of breast cancer cells grown on 3D bone-mimetic scaffolds using quasi-static and dynamic nanoindentation methods and correlated cell mechanics changes with dysregulation in actin cytoskeleton dynamics using fluorescence staining and mRNA expression of cytoskeleton-related genes.

\section{Results. Cancer cells alter cell mechanics in response to 3D culture condition}

According to the procedure described in our previous study, we have created a 3D in vitro model for breast cancer bone metastasis, mimicking MET of breast cancer in the sequential culture of osteogenically differentiated MSCs and breast cancer cells study ${ }^{77}$. Briefly, MSCs were cultured on 3D scaffolds for 23 days to generate bone tissue. Then, human breast cancer cells were seeded on the newly formed bone matrix (Fig. 1a). We observed the formation of tumoroids with distinguishable cellular boundaries by MCF-7 cells, whereas MM 231 cells formed disordered cellular aggregates, as shown in Fig. 1b. Displacement-controlled nanoindentation experiments at maximum displacements of $1000 \mathrm{~nm}$ and $2000 \mathrm{~nm}$ were performed to obtain mechanical properties of breast cancer cells and elastic moduli were calculated using Oliver-Pharr method ${ }^{83}$. The Oliver-Pharr method takes the unloading load-indentation curve into consideration and therefore is more suitable for capturing a viscoelastic rather than a purely elastic response.

In contrast, other methods such as Hertz and Sneddon lack plastic deformation in the force regime probed for biological materials. Displacement-controlled nanoindentation experiments at maximum displacements of $1000 \mathrm{~nm}$ and $2000 \mathrm{~nm}$ were performed using TRIBOSCOPE, (Hysitron, Minneapolis, MN) equipped with 
(a)

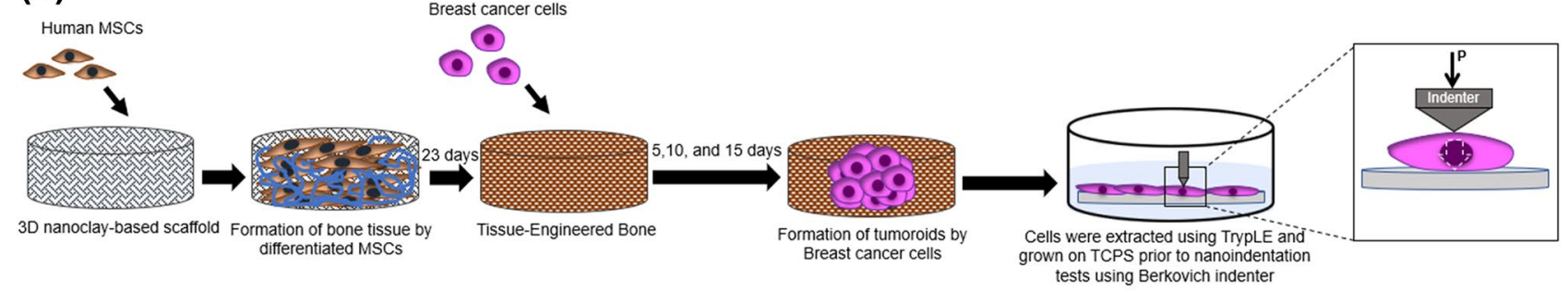

(b)
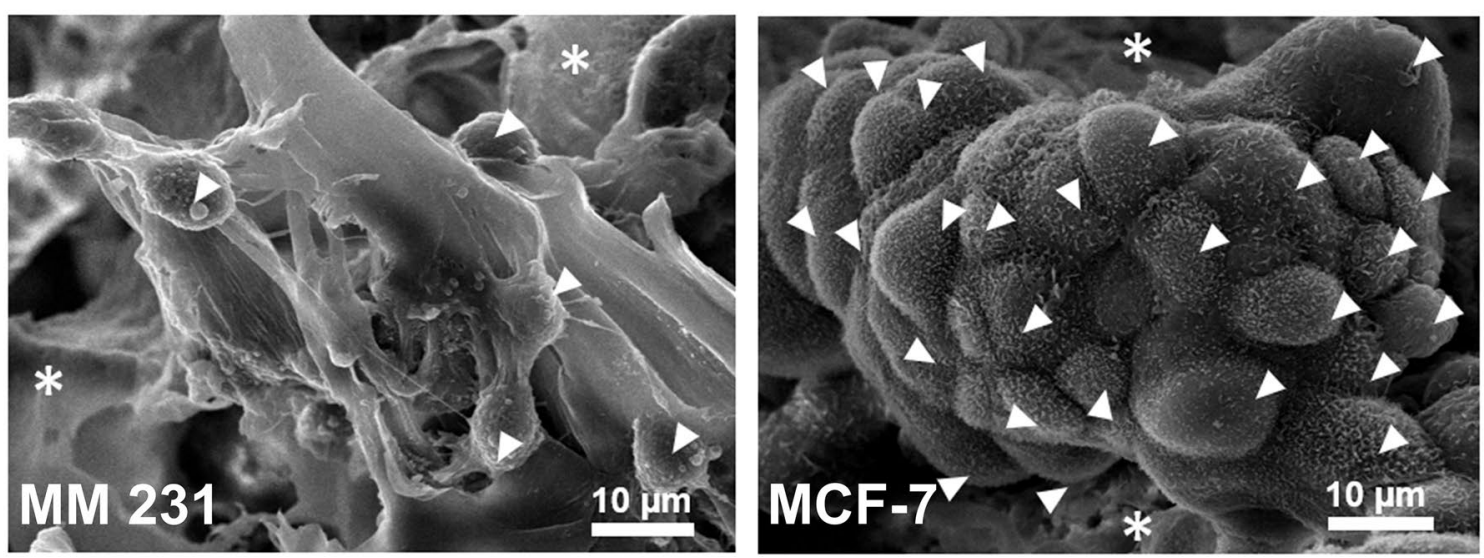

Figure 1. (a) Schematic showing steps of sequential culture MSCs/breast cancer followed by workflow of nanoindentation experiment. Dotted arrow pointing downwards indicates the amount of deformation applied (P) onto cell to obtain mechanical response. (b) Morphology of breast cancer cells MM 231 and MCF-7 grown on 3D bone-mimetic nanoclay scaffolds. Arrows indicate cells while ${ }^{\star}$ indicate scaffold.

multimode AFM (NANOSCOPE IIIa controller and J-type piezo scanner system) (Veeco Metrology, Santa Barbara, CA) and a Berkovich diamond indenter fluid tip (three-sided pyramidal; 100-200 nm tip radius). Although earlier studies have used blunt tips for indenting human biological tissue samples ${ }^{47}$, several recent studies have shown that cell stiffness measured by sharp indenters is comparable to stiffness measured by blunt tips ${ }^{84,85}$. Also, sharper tips enable information on the localized mechanical properties from deeper penetration into the probed sample with little to no detrimental effect easily compared to blunt tips ${ }^{45,85}$.

Indentation depth has been shown to influence the measurement of the elastic modulus of cells. The mechanical properties observed at $\sim 300-500 \mathrm{~nm}$ arise from cellular membrane and peripheral structures, whereas, at deeper indentation ( 1000-2000 nm), the bulk mechanical property of cell can be obtained ${ }^{85}$. The bulk mechanical property of cells arises predominantly from cytoskeletal components such as actin filaments, microtubules, and intermediate filaments ${ }^{3}$. The elastic modulus of each component is given in Table S2. Keeping these facts mentioned above in mind, we used two different indentation depths, $1000 \mathrm{~nm}$ and $2000 \mathrm{~nm}$, for displacement controlled nanoindentation experiments. The representative load-displacement (L-D) curves for as-received and 3D bone-mimetic scaffolds-derived MCF-7 cells at the indentation depth of $1000 \mathrm{~nm}$ and $2000 \mathrm{~nm}$ are shown in Fig. 2a, and the respective elastic moduli are indicated in the figures. Figure $2 \mathrm{~b}$ shows the variation of elastic modulus between as-received and 3D bone-mimetic scaffolds-derived MCF-7 cells at the maximum indentation depth of $1000 \mathrm{~nm}$ and $2000 \mathrm{~nm}$.

We observed that both $E_{1000 \mathrm{~nm}}$ and $E_{2000 \mathrm{~nm}}$ of scaffolds-derived MCF-7 cells are significantly lower than that of MCF-7 as-received cells. We further observed a significant decrease within the scaffolds-derived MCF-7 cells with an increasing number of days at both 1000 and $2000 \mathrm{~nm}$. It is noteworthy to mention that elastic modulus decreased with increasing indentation depth. At $1000 \mathrm{~nm}$, the mean elastic modulus of MCF-7 as-received, and scaffolds-derived MCF-7 (d5), MCF-7 (d10), and MCF-7 (d15) were 12.92 $\pm 1.81 \mathrm{MPa}, 8.37 \pm 0.81 \mathrm{MPa}$, $4.85 \pm 0.65 \mathrm{MPa}$, and $2.25 \pm 0.57 \mathrm{MPa}$, respectively. At $2000 \mathrm{~nm}$, the mean elastic modulus of MCF-7 as-received, and scaffolds-derived MCF-7 (d5), MCF-7 (d10), and MCF-7 (d15) were 5.50 $\pm 0.83 \mathrm{MPa}, 3.98 \pm 0.54 \mathrm{MPa}$, $2.23 \pm 0.32 \mathrm{MPa}$, and $1.14 \pm 0.18 \mathrm{MPa}$, respectively.

The representative L-D curves for as-received and 3D bone-mimetic scaffolds-derived MM 231 cells at the indentation depth of $1000 \mathrm{~nm}$ and $2000 \mathrm{~nm}$ are shown in Fig. 3a, and the respective elastic modulus or $E$ values are indicated in the figures. Figure $3 \mathrm{~b}$ shows the elastic modulus of as-received and 3D bone-mimetic scaffoldsderived MM 231 cells at the maximum indentation depth of $1000 \mathrm{~nm}$ and $2000 \mathrm{~nm}$. There was no significant difference between elastic moduli of as-received and 3D bone-mimetic scaffolds-derived MM 231 cells at both $1000 \mathrm{~nm}$ and $2000 \mathrm{~nm}$. We further observed insignificant differences in elastic modulus of scaffolds-derived MM 231 cells with an increasing number of days at both 1000 and $2000 \mathrm{~nm}$. We once again observed a reduction in elastic modulus with increasing indentation depth. At $1000 \mathrm{~nm}$, the mean elastic modulus of MM 231 as-received, and scaffolds-derived MM 231 (d5), MM 231 (d10), and MM 231 (d15) were 10.62 $\pm 0.95 \mathrm{MPa}, 10.00 \pm 1.07 \mathrm{MPa}$, 
(a)
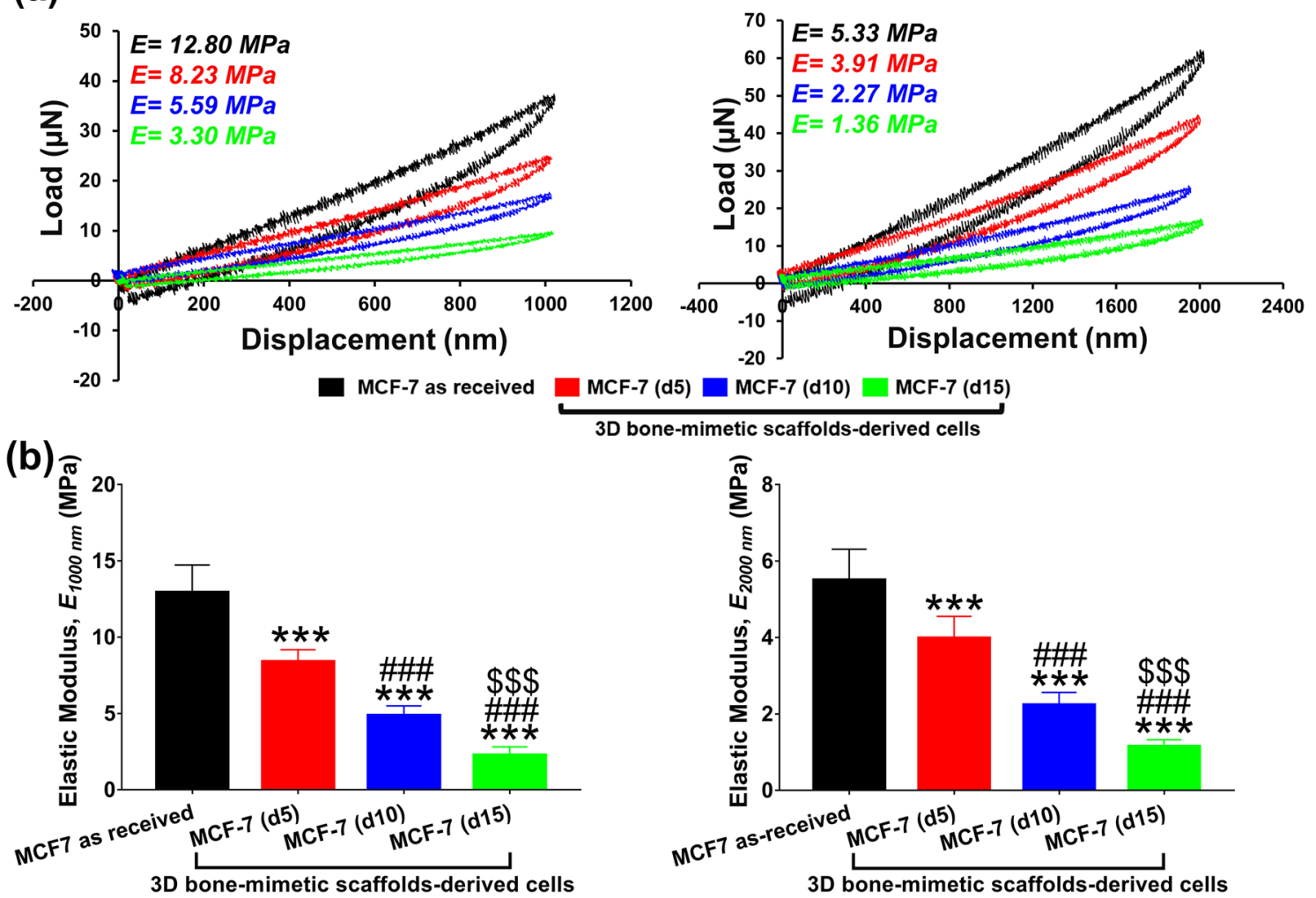

3D bone-mimetic scaffolds-derived cells

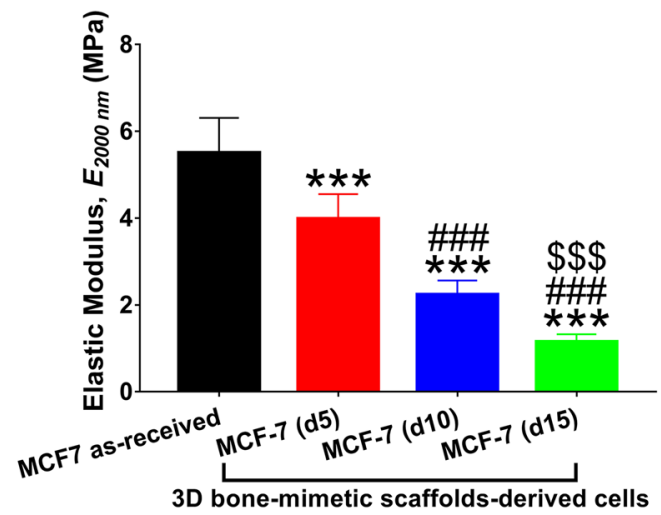

Figure 2. (a) Representative load-displacement (L-D) curves of MCF-7 as received, and 3D bone-mimetic scaffolds-derived MCF-7 cells at the maximum depth of $1000 \mathrm{~nm}$ and $2000 \mathrm{~nm}$. (b) Elastic modulus of MCF-7 as received and 3D bone-mimetic scaffolds-derived MCF-7 cells at the maximum depth of $1000 \mathrm{~nm}$ and $2000 \mathrm{~nm}$. For each measured sample, at least 20 cells were measured. Data are reported as a mean \pm standard deviation (SD). ${ }^{*} \mathrm{p}<0.05,{ }^{* *} \mathrm{p}<0.01$, and ${ }^{* * *} \mathrm{p}<0.001$ indicate significant difference between MCF-7 as received and 3D bone-mimetic scaffolds-derived MCF-7 cells; ${ }^{\#} \mathrm{p}<0.05,{ }^{\# \#} \mathrm{p}<0.01$, and ${ }^{\# \# \#} \mathrm{p}<0.001$ indicate significant difference between scaffolds-derived MCF-7 (d5), and other scaffolds-derived cells (i.e., MCF-7 (d10) and MCF-7 (d15)); ${ }^{\$}<<0.05,{ }^{\$} \mathrm{p}<0.01$, and ${ }^{\$ \$} \mathrm{p}<0.001$ indicate significant difference between scaffolds-derived MCF-7 (d10) and MCF-7 (d15).

$9.88 \pm 0.93 \mathrm{MPa}$, and $9.82 \pm 0.94 \mathrm{MPa}$, respectively. At $2000 \mathrm{~nm}$, the mean elastic modulus of MM 231 as-received, and scaffolds-derived MM 231 (d5), MM 231 (d10), and MM 231 (d15) were $4.65 \pm 0.49 \mathrm{MPa}, 4.46 \pm 0.52 \mathrm{MPa}$, $4.39 \pm 0.41 \mathrm{MPa}$, and $4.31 \pm 0.27 \mathrm{MPa}$, respectively. Overall, MCF-7 showed a progressive reduction in elastic modulus compared to MM 231 when cultured in 3D bone-mimetic scaffolds.

Cancer cells behave more liquid-like when cultured in 3D culture condition. The storage modulus $\left(E^{\prime}.\right)$, loss modulus $\left(E^{\prime \prime}\right)$, and loss tangent $(\tan \delta)$ of as-received and scaffolds-derived breast cancer cells (MCF-7 and MM 231) are shown in Fig. 4. Storage moduli of both cells across samples were found to be in the same range as elastic moduli reported in the previous section. For example, storage modulus of MCF-7 asreceived, and scaffolds-derived MCF-7 (d5), MCF-7 (d10), and MCF-7 (d15) were 13-14 MPa, 6-8 MPa, 3-6 MPa, and 3-4 MPa, respectively (Fig. 4a). In the case of MM 231, the storage moduli of as-received and scaffolds-derived d5, d10, and d15 we 8-10 MPa, 6-9 MPa, 5-7 MPa, and 5-7 MPa, respectively (Fig. 4b). Loss moduli values for both cells across samples were in the same range. For instance, loss moduli of as-received MCF-7/MM 231, and scaffolds-derived MCF-7/MM 231 (d5), MCF-7/MM 231 (d10), and MCF-7/MM231 (d15) cells were $\sim 3-5 \mathrm{MPa}, \sim 2-4 \mathrm{MPa}, \sim 2-4 \mathrm{MPa}$, and 2-3 MPa, respectively (Fig. 4c, d). It should be noted that both cells' storage and loss moduli across conditions seem to be independent of frequency. Interestingly, we found an increase in loss tangent $(\tan \delta$ ) with increasing frequency for both cells grown in TCPS (as-received). In other words, cells became more viscous (higher loss tangent, indicating more viscous behavior) at higher frequencies. Next, we assessed whether growing cells on scaffolds altered the viscoelastic properties of the cells. For scaffolds-derived MCF-7 (d5), we noticed an increase in $\tan \delta$ with increasing frequency, but it never exceeded the value of 1 . Interestingly, $\tan \delta$ values were found to be higher than 1 for both MCF-7 (d10) and MCF-7 (d15) at $199 \mathrm{~Hz}$ (and beyond) and $165 \mathrm{~Hz}$ (and beyond), respectively. The frequency at which cells transition from solid-like to liquid-like (more viscous) $(\tan \delta=1)$ is termed as transition frequency $\left(\omega_{\text {transition }}\right)$, as shown by the intersecting dashed lines (Fig. 4e). Based on transition frequency, scaffolds-derived MCF-7 (d15) was found to be more liquid-like as compared to MCF-7 (d10). In the case of scaffolds-derived MM 231 cells, we observed no significant increase in $\tan \delta$ values over time (Fig. 4 f). 
(a)
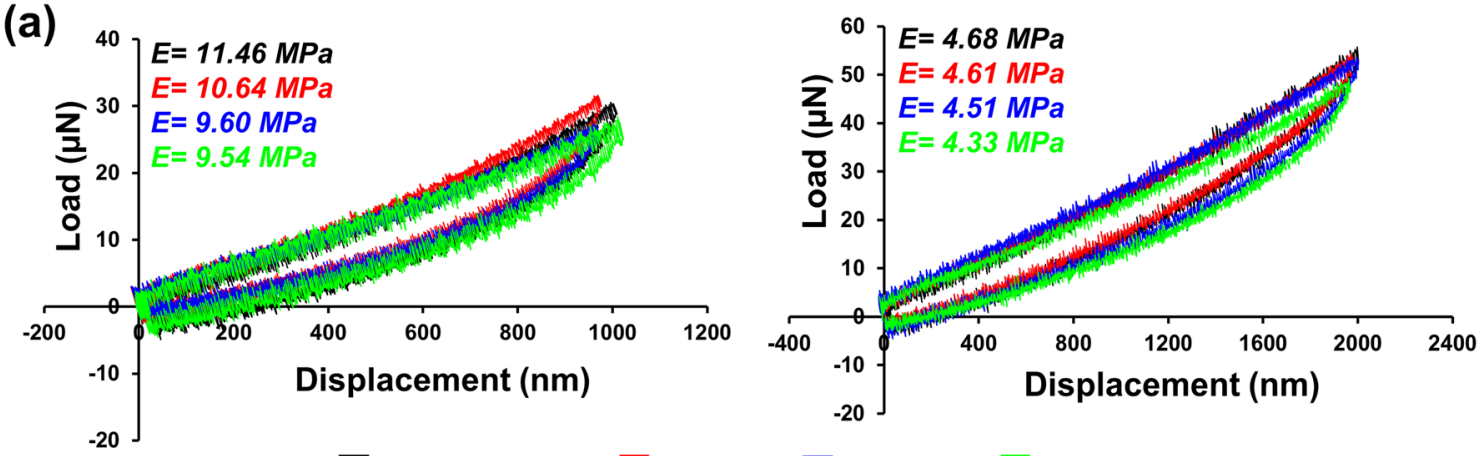

MM 231 as received $\square$ MM 231 (d5) $\square$ MM 231 (d10) $\square$ MM 231 (d15)

(b)

3D bone-mimetic scaffolds-derived cells
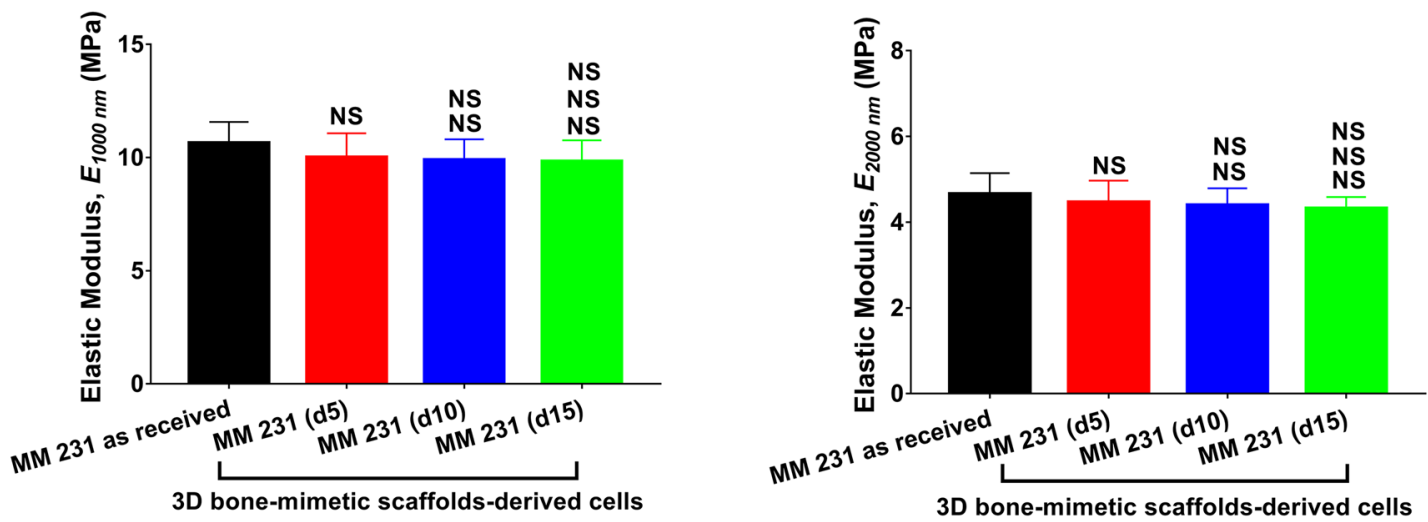

Figure 3. (a) Representative load-displacement (L-D) curves of MM 231 as received, and 3D bone-mimetic scaffolds-derived MM 231 cells at the maximum depth of $1000 \mathrm{~nm}$ and $2000 \mathrm{~nm}$. (b) Elastic modulus of MM 231 as received and 3D bone-mimetic scaffolds-derived MM 231 cells at the maximum depth of $1000 \mathrm{~nm}$ and $2000 \mathrm{~nm}$. For each measured sample, at least 20 cells were measured. Data are reported as a mean \pm standard deviation (SD). ${ }^{\star} \mathrm{p}<0.05,{ }^{* *} \mathrm{p}<0.01$, and ${ }^{* * *} \mathrm{p}<0.001$ indicate significant difference between MM 231 as received and 3D bone-mimetic scaffolds-derived MM 231 cells; ${ }^{\#} \mathrm{p}<0.05,{ }^{\# \#} \mathrm{p}<0.01$, and ${ }^{\# \# \#} \mathrm{p}<0.001$ indicate significant difference between scaffolds-derived MM 231 (d5), and other scaffolds-derived cells (i.e., MM 231 (d10) and MM $231(\mathrm{~d} 15)) ;{ }^{\$} \mathrm{p}<0.05,{ }^{\$ \$} \mathrm{p}<0.01$, and ${ }^{\$ \$} \mathrm{p}<0.001$ indicate significant difference between scaffolds-derived MM 231 (d10) and MM 231 (d15).

We could not determine the transition frequency for MM 231 as tan $\delta$ values never went beyond 1. It should be noted that our results are in good agreement with recent studies done on breast cancer cells using highfrequency microrheology based methods ${ }^{86,87}$, and AFM indentation studies ${ }^{19}$. To compare the storage modulus $\left(E^{\prime}\right)$, loss modulus $\left(E^{\prime \prime}\right)$, and loss tangent $(\tan \delta)$ of as-received and bone-site breast cancer cells (MCF-7 and MM 231), we calculated $\log 2$ ratios of $E^{\prime}, E^{\prime \prime}$, and $\tan \delta$ for MCF-7 and MM 231 across samples (averaged across frequency) (Figure S1).

We observed a significant decrease in the storage of modulus of scaffolds-derived MCF-7 over scaffoldsderived MM 231 cells over time, as compared to their respective as-received counterparts (Figure S1a). In the case of loss modulus, scaffolds-derived MCF-7 showed a significant increase over scaffolds-derived MM 231 at day 5, compared to their respective as-received counterparts. However, we observed insignificant changes at day 10 and day 15 regarding loss modulus as both cells approached the liquid-like phase during the experiment (Figure S1b). Interestingly, we found a substantial increase in $\tan \delta$ of scaffolds-derived MCF-7 cells over scaffolds-derived MM 231 over time (Figure S1c), further confirming our observation in Fig. 4e,f. Overall, MCF-7 cells showed more liquid-like behavior than MM 231 cells when cultured in 3D bone-mimetic scaffolds.

Reorganization of cytoskeleton influences cell mechanics during cancer progression. To investigate whether the observed changes in elastic moduli and viscoelastic properties were correlated to structural rearrangements of cytoskeletal components, we performed immunofluorescence staining on as-received and scaffolds-grown counterparts of both cancer cells. Representative immunofluorescence images of F-actin and $\alpha$-tubulin stained as-received MCF-7/MM 231 and MCF-7/MM 231 cells grown on 3D-bone-mimetic scaffolds are shown in Figs. 5 and S2. The immunofluorescence images showed a significant reduction in F-actin intensity in scaffolds-grown MCF-7 cells compared to MCF-7 as-received cells. Still, regardless of culture type, there was no significant difference in the intensity of $\alpha$-tubulin (Fig. 5a). Furthermore, the F-actin network of asreceived MCF-7 consisted of evenly distributed short fibers. MCF-7 cells grown on scaffolds showed thin F-actin band formation between adjacent cells (indicated by small white arrows in Fig. 5a). We calculated the corrected total cell fluorescence (CTCF) of F-actin and $\alpha$-tubulin for as-received and scaffolds-grown MCF-7 cells to fur- 
(a)

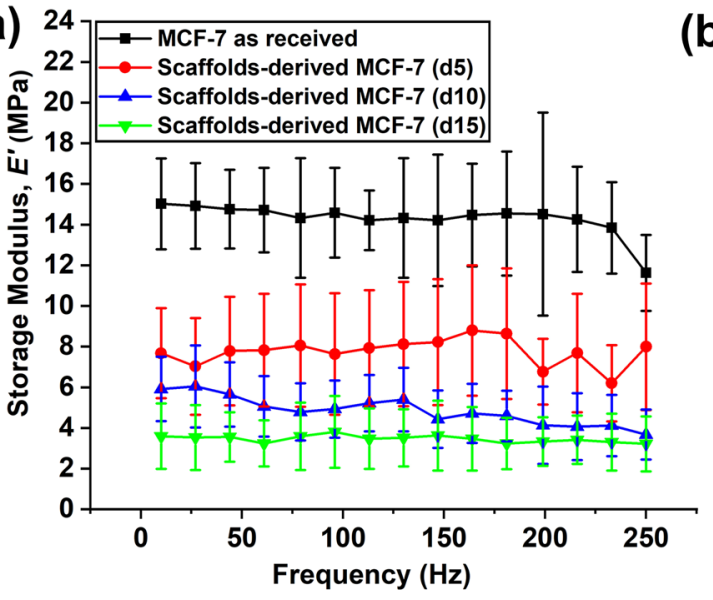

(c)

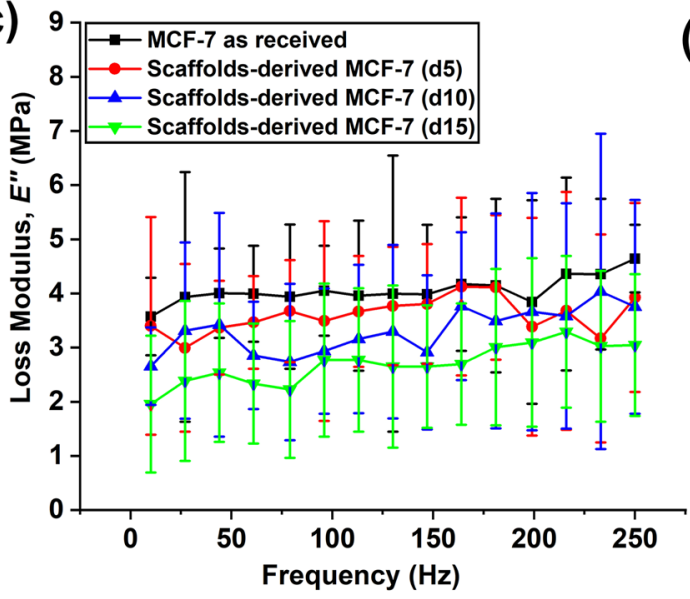

(b)

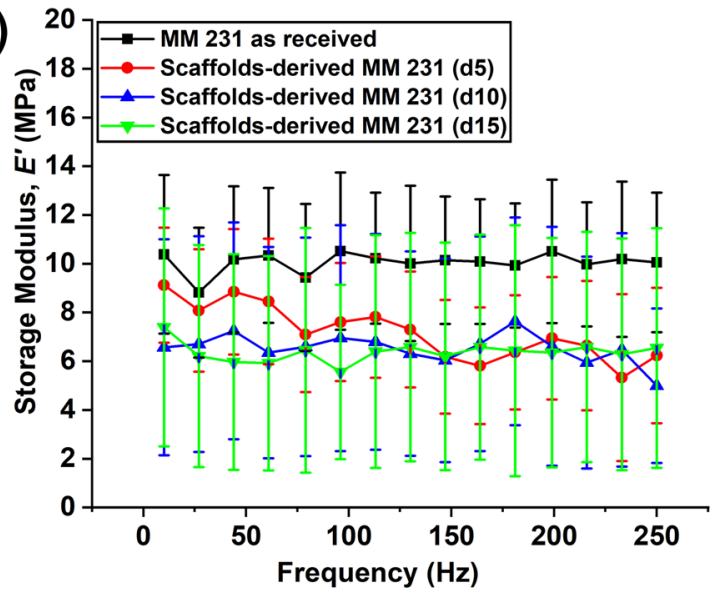

(d)

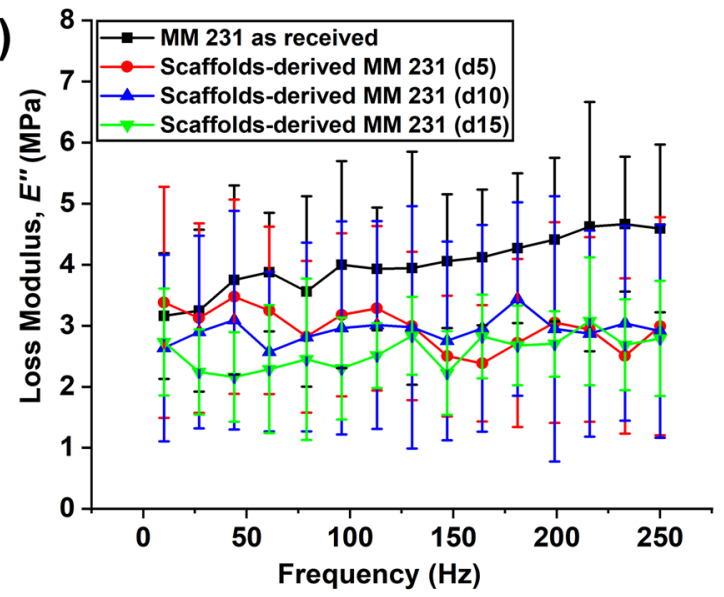

(e)

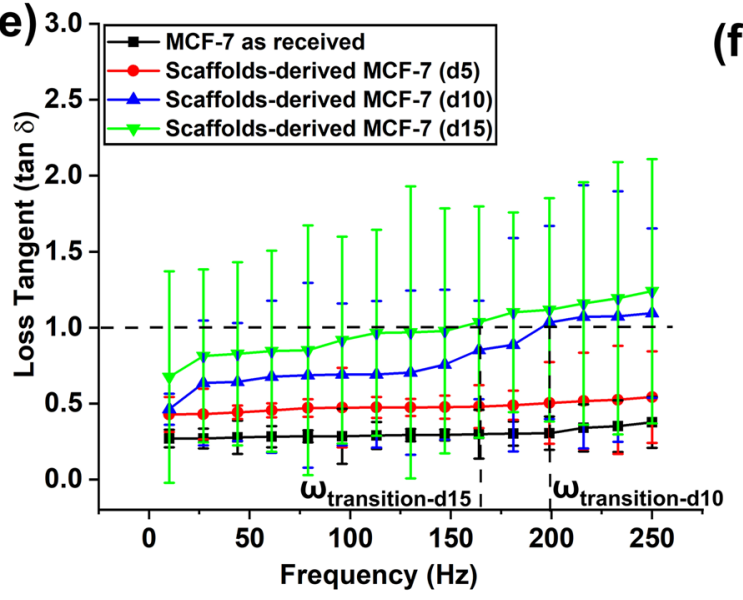

(f)

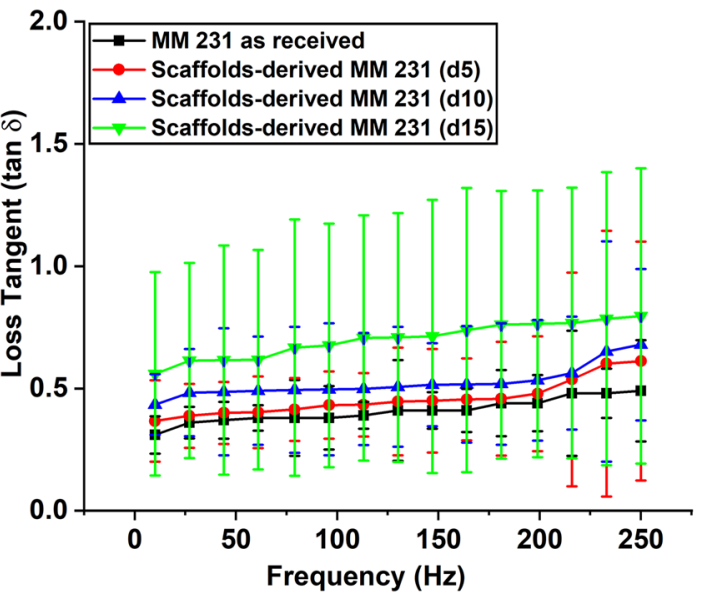

Figure 4. Variation of storage modulus ( $\left.E^{\prime}\right)$ for (a) MCF-7 as received and 3D bone-mimetic scaffolds-derived MCF-7 cells; (b) MM 231 as received and 3D bone-mimetic scaffolds-derived MM 231 cells. Variation of loss modulus ( $\left.E^{\prime \prime}\right)$ for (c) MCF-7 as received and 3D bone-mimetic scaffolds-derived MCF-7 cells; (d) MM 231 as received and 3D bone-mimetic scaffolds-derived MM 231 cells. Variation of loss tangent (tan $\delta$ ) for (e) MCF-7 as received and 3D bone-mimetic scaffolds-derived MCF-7 cells; (f) MM 231 as received and 3D bone-mimetic scaffolds-derived MM 231 cells. Intersections with the horizontal dashed line at $\tan \delta=1$ of the vertical lines occur at transition frequencies, $\omega_{\text {transition}}$.

ther validate our observation. We found $60.47 \%, 79.44 \%$, and $95.60 \%$ reduction in the intensity of F-actin from as-received to scaffolds-grown MCF-7 (d5), MCF-7 (d10), and MCF-7 (d15), respectively (Fig. 5c); however, we observed no significant changes in the intensity of a-tubulin, as shown in Figure S2a, c. As-received MM 231 
Cells grown on 3D bone-mimetic scaffolds

(a)

MCF-7 as received
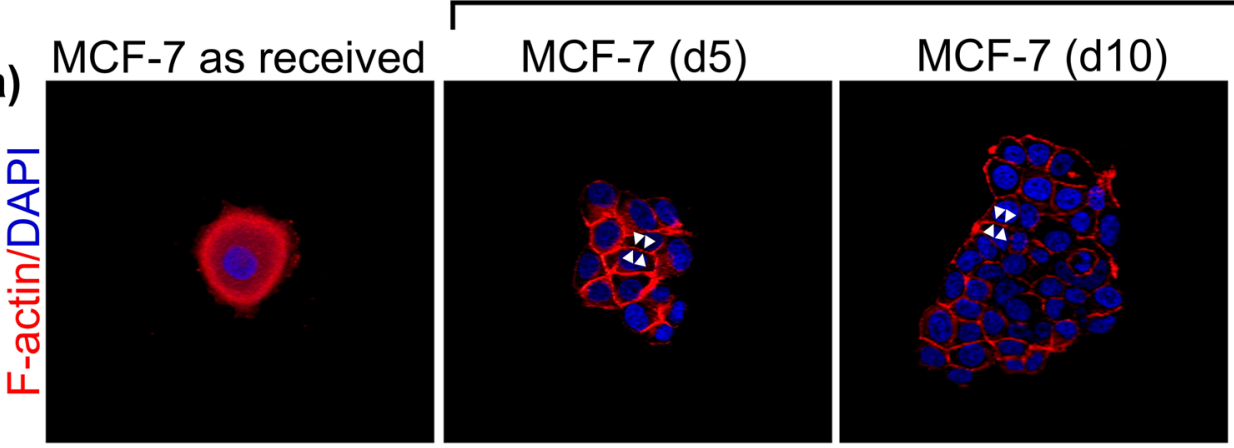

MCF-7 (d15)

(b)
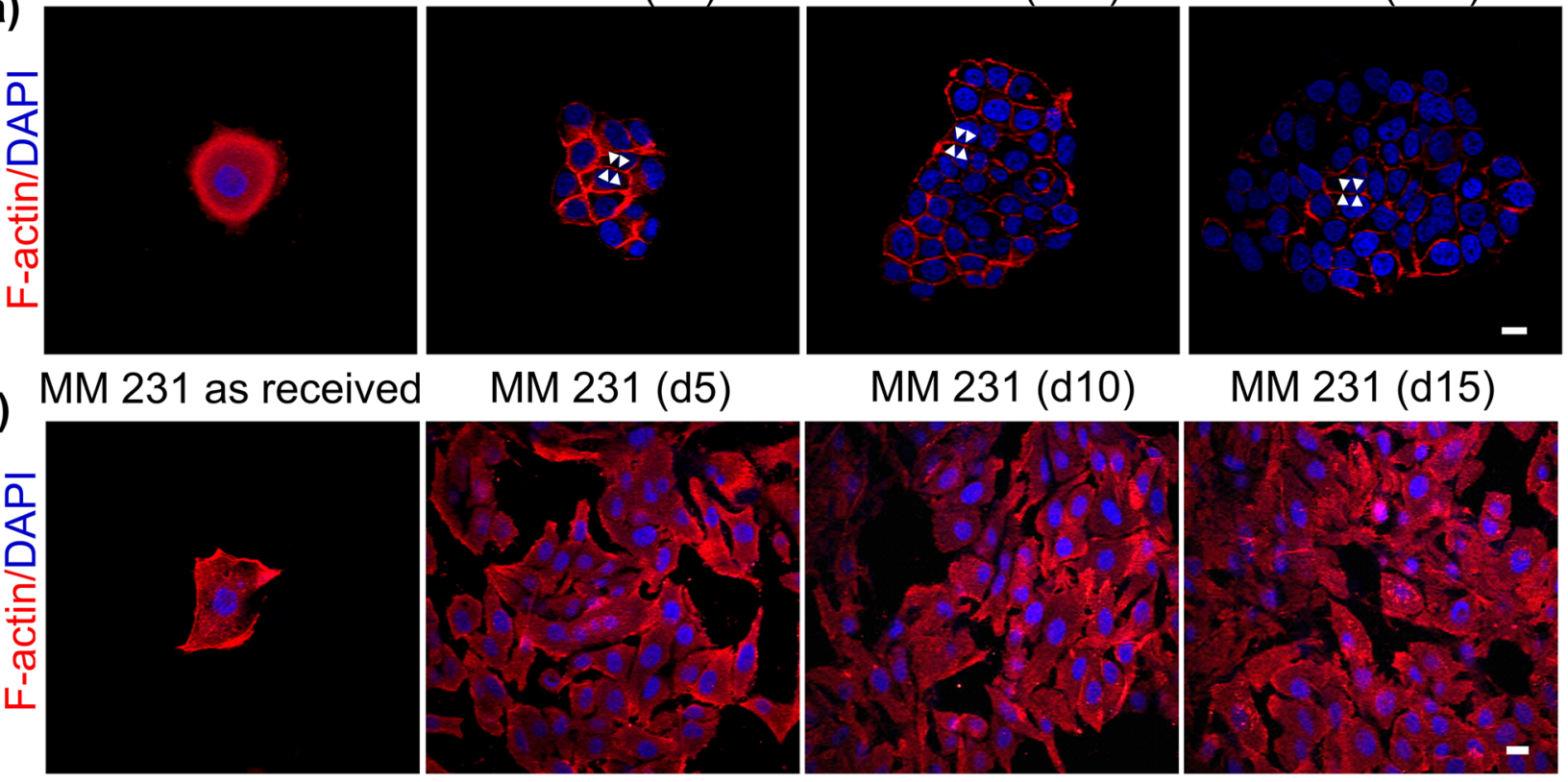

MM $231(\mathrm{~d} 15)$

(c)

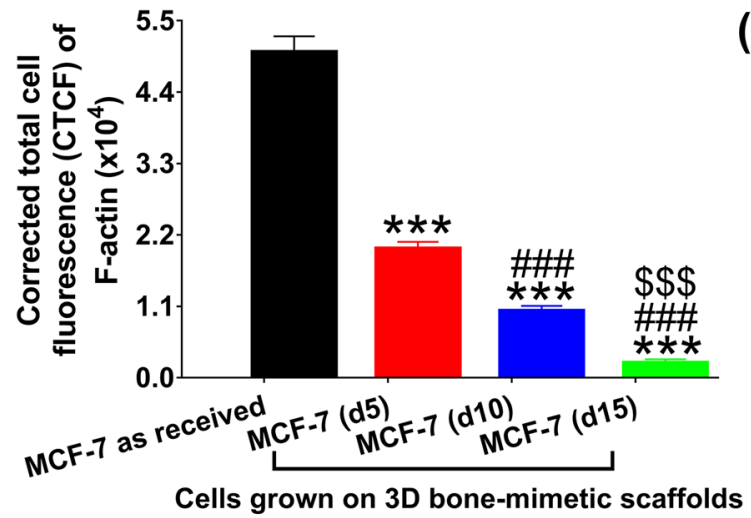

(d)

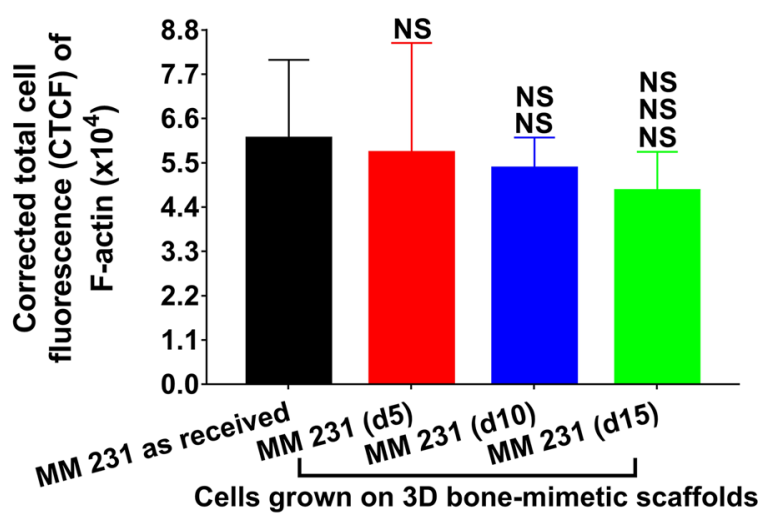

Figure 5. Representative immunofluorescence images showing distribution of F-actin in (a) MCF-7 as received and MCF-7 cells grown on 3D bone-mimetic scaffolds. Scaffolds grown MCF-7 formed an F-actin band (shown by white arrows) between adjacent cells; (b) MM 231 as received and MM 231 cells grown on 3D bone-mimetic scaffolds. Scaffolds grown MM 231 neither formed an F-actin band between adjacent cells nor stress-fibers. Scale bars: $10 \mu \mathrm{m}$. Quantification of corrected total cell fluorescence (CTCF) of F-actin for (c) MCF-7 as received and MCF-7 cells grown on 3D bone-mimetic scaffolds; (d) MM 231 as received and MM 231 cells grown on $3 \mathrm{D}$ bone-mimetic scaffolds. For each measured sample, at least 5-6 cells were measured. Data are reported as a mean \pm standard deviation (SD). ${ }^{*} \mathrm{p}<0.05,{ }^{* *} \mathrm{p}<0.01$, and ${ }^{* *} \mathrm{p}<0.001$ indicate significant difference between as received and $3 \mathrm{D}$ bone-mimetic scaffolds-grown breast cancer cells; ${ }^{\#} \mathrm{p}<0.05,{ }^{\# \#} \mathrm{p}<0.01$, and ${ }^{\# \# \#} \mathrm{p}<0.001$ indicate significant difference between scaffolds-grown breast cancer cells (d5), and other scaffolds-grown breast cancer cells (i.e., (d10) and (d15)); ${ }^{\$} \mathrm{p}<0.05,{ }^{\$ \$} \mathrm{p}<0.01$, and ${ }^{\$ \$} \mathrm{p}<0.001$ indicate significant difference between scaffoldsgrown breast cancer cells (d10) and (d15).

cells exhibited an F-actin network consisted of short fibers (Fig. 5b). The organization of the actin cytoskeleton did not change significantly from as-received to scaffolds-grown MM 231 cells. MM 231 cells grown on scaffolds neither formed stress fibers nor an F-actin band between adjacent cells, as shown in Fig. 5b. We once again observed no significant changes in a-tubulin intensity between as-received and scaffolds-grown MM 231 cells (Figure S2b). Furthermore, quantitative analysis of F-actin (Fig. 5d) and a-tubulin fluorescence (Figure S2d) performed on as received and scaffolds-grown MM 231 cells showed good agreement with the observations made in Figs. 5b and S2b, respectively.

It was previously shown that actin filaments affect the mechanical properties of cells and not microtubules ${ }^{24,88}$. Our results are in good agreement with previous studies. The observations mentioned above prompted us to evaluate the expression of genes related to actin dynamics. We evaluated the expression of CDC42, ARP2, ARP3, 

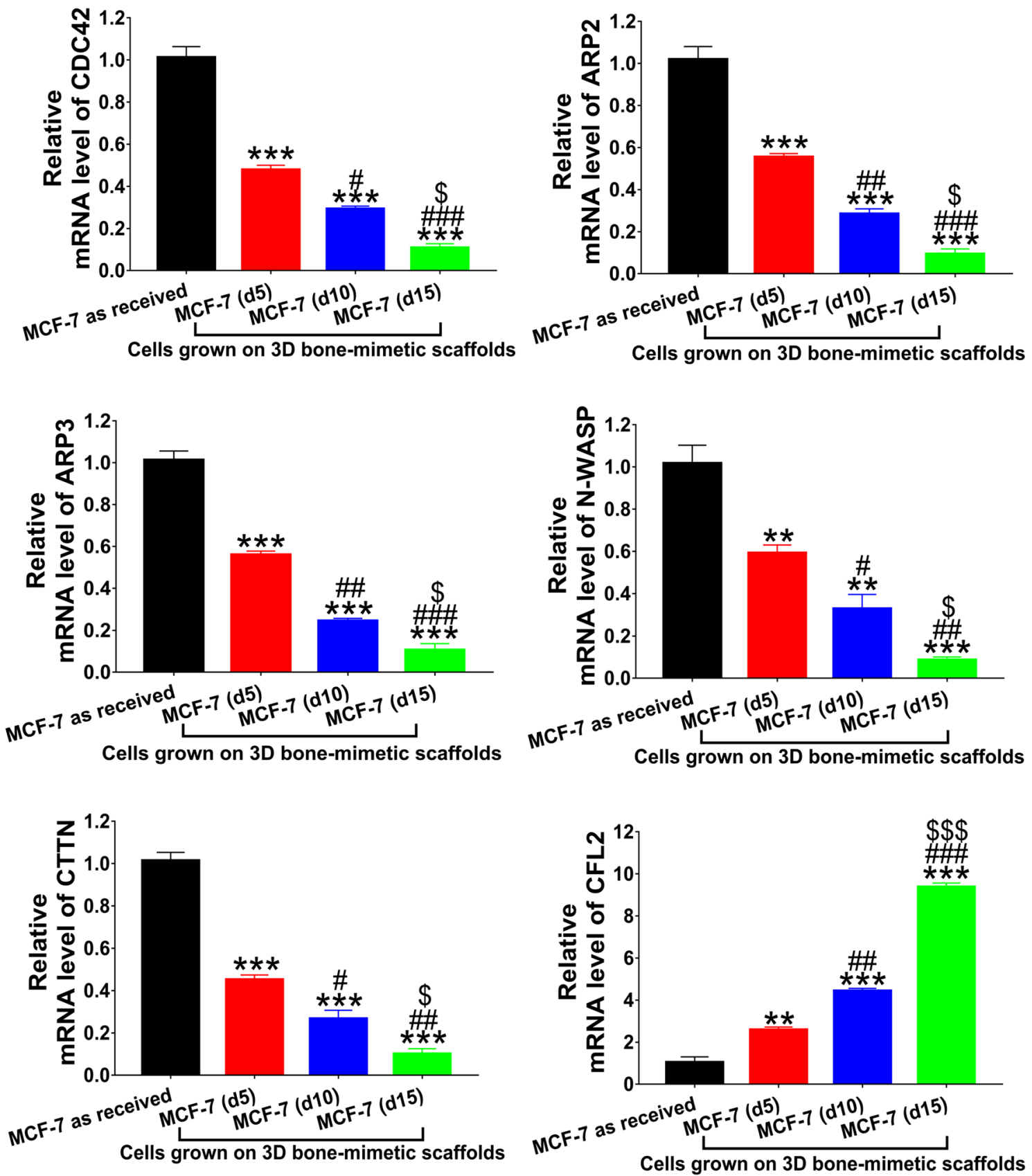

Figure 6. Quantitative real-time PCR of gene expression for actin dynamics-related genes CDC42, ARP2, ARP3, N-WASP, CTTN, and CFL2. ${ }^{\star} \mathrm{p}<0.05,{ }^{* *} \mathrm{p}<0.01$, and ${ }^{* * *} \mathrm{p}<0.001$ indicate significant difference between MCF-7 as received and MCF-7 cells grown on $3 \mathrm{D}$ bone-mimetic scaffolds; ${ }^{\#}<<0.05,{ }^{\# \#} \mathrm{p}<0.01$, and ${ }^{\# \# \#} \mathrm{p}<0.001$ indicate significant difference between MCF-7 (d5) cells grown on 3D bone-mimetic scaffolds, and other MCF-7 cells grown on 3D bone-mimetic scaffolds (i.e., MCF-7 (d10) and MCF-7 (d15)); ${ }^{\$} \mathrm{p}<0.05,{ }^{\$} \mathrm{p}<0.01$, and $\$ \$ p<0.001$ indicate significant difference between MCF-7 (d10) and MCF-7 (d15) cells grown on 3D bonemimetic scaffolds.

N-WASP, CTTN, and CFL2 at the mRNA level. Figure 6 shows the expression of these genes for both as-received and scaffolds-grown MCF-7 cells. CDC42, ARP2, ARP3, N-WASP, and CTTN showed reduction at the mRNA level by 1.70-2.20 fold, 3-4 fold, and 9-12 fold in scaffolds-grown MCF-7 (d5), MCF-7 (d10), and MCF-7 (d15), respectively, compared to as-received MCF-7. Interestingly, we observed an upregulation in CFL2 expression level by 2.58 fold, 4.42 fold, and 9.37 fold in scaffolds-grown MCF-7 (d5), MCF-7 (d10), and MCF-7 (d15), respectively, compared to as-received MCF-7. In the case of MM 231, we observed no significant changes in the expression levels of all the genes evaluated for both as-received and scaffolds-grown cells over time, as shown in Fig. 7. The schematic diagram shown in Fig. 8a shows how actin regulatory proteins mediate the reorganization of the actin cytoskeleton during MET. The mechanism of F-actin depolymerization and reorganization based on our observations is shown in Fig. $8 \mathrm{~b}$. 

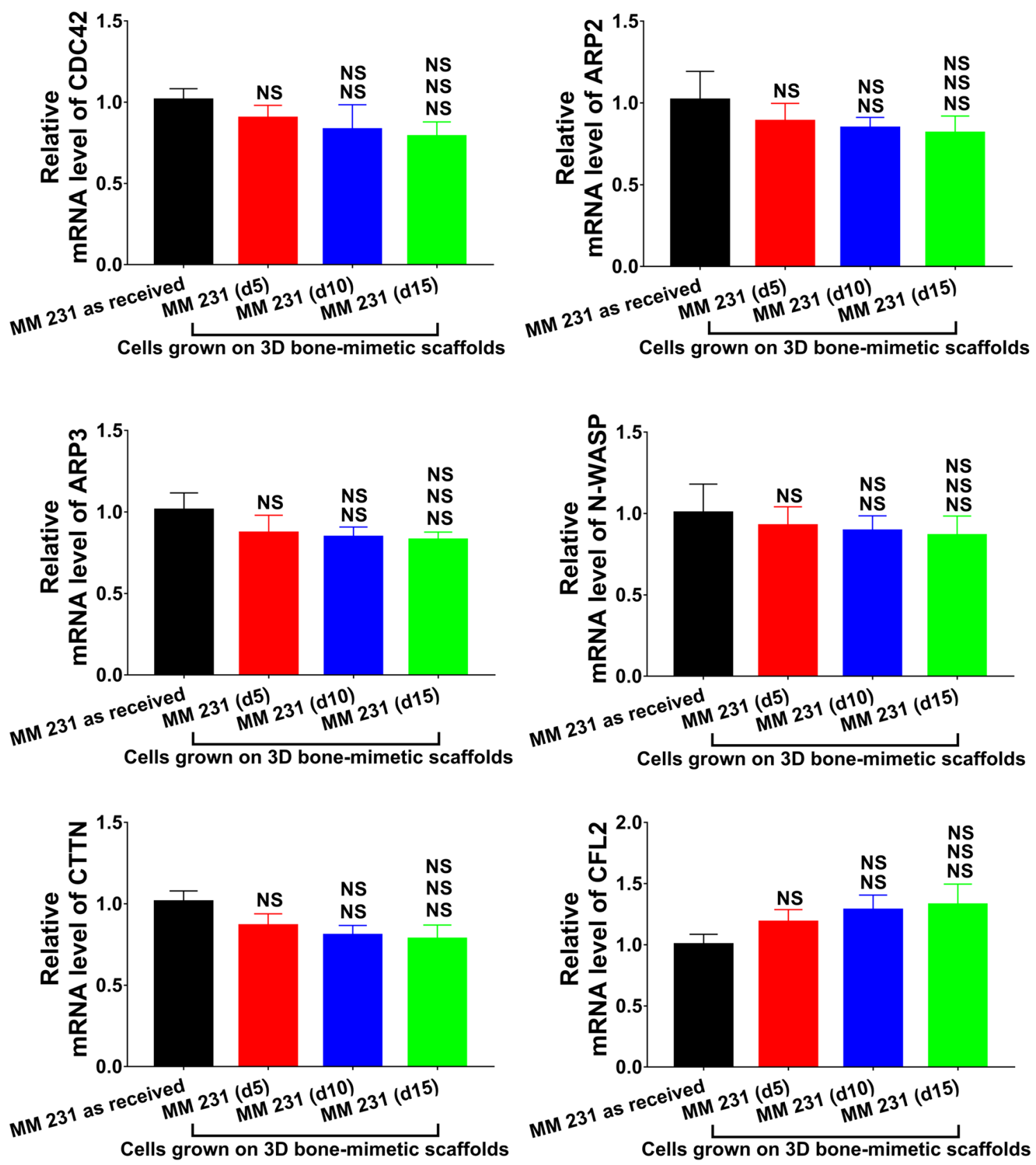

Figure 7. Quantitative real-time PCR of gene expression for actin dynamics-related genes CDC42, ARP2, ARP3, N-WASP, CTTN, and CFL2. ${ }^{*} \mathrm{p}<0.05,{ }^{* *} \mathrm{p}<0.01$, and ${ }^{* * *} \mathrm{p}<0.001$ indicate significant difference between MM 231 as received and MM 231 cells grown on $3 \mathrm{D}$ bone-mimetic scaffolds; ${ }^{\#} \mathrm{p}<0.05,{ }^{\# \#} \mathrm{p}<0.01$, and $\# \#$ $\mathrm{p}<0.001$ indicate significant difference between MM 231 (d5) cells grown on 3D bone-mimetic scaffolds, and other MM 231 cells grown on 3D bone-mimetic scaffolds (i.e., MM 231 (d10) and MM $231(\mathrm{~d} 15)$ ) ; ${ }^{\$} \mathrm{p}<0.05$, ${ }^{\$ \$} \mathrm{p}<0.01$, and ${ }^{\$ \$} \mathrm{p}<0.001$ indicate significant difference between MM 231 (d10) and MM 231 (d15) cells grown on $3 \mathrm{D}$ bone-mimetic scaffolds.

Taken together, these expeiments indicate that actin dynamics seems to regulate cell mechanics during cancer progression, and MCF-7 cells exhibited a substantial reorganization of actin cytoskeleton when cultured in 3D bone-mimetic scaffolds as compared to MM 231 cells.

\section{Discussion}

We investigated the mechanical properties of as-received and 3D bone-mimetic scaffolds-derived breast cancer cells (MCF-7 and MM 231). We found that the bone-site or scaffolds-derived MCF-7 cells exhibit dramatic changes in elastic modulus and demonstrate liquid-like behavior over time compared to MCF-7 as-received cells. In contrast, the bone-site or scaffolds-derived MM 231 cells neither showed significant changes in elastic modulus nor exhibited liquid-like behavior over time than as-received MM 231 cells. Higher loss tangent values 
(a)

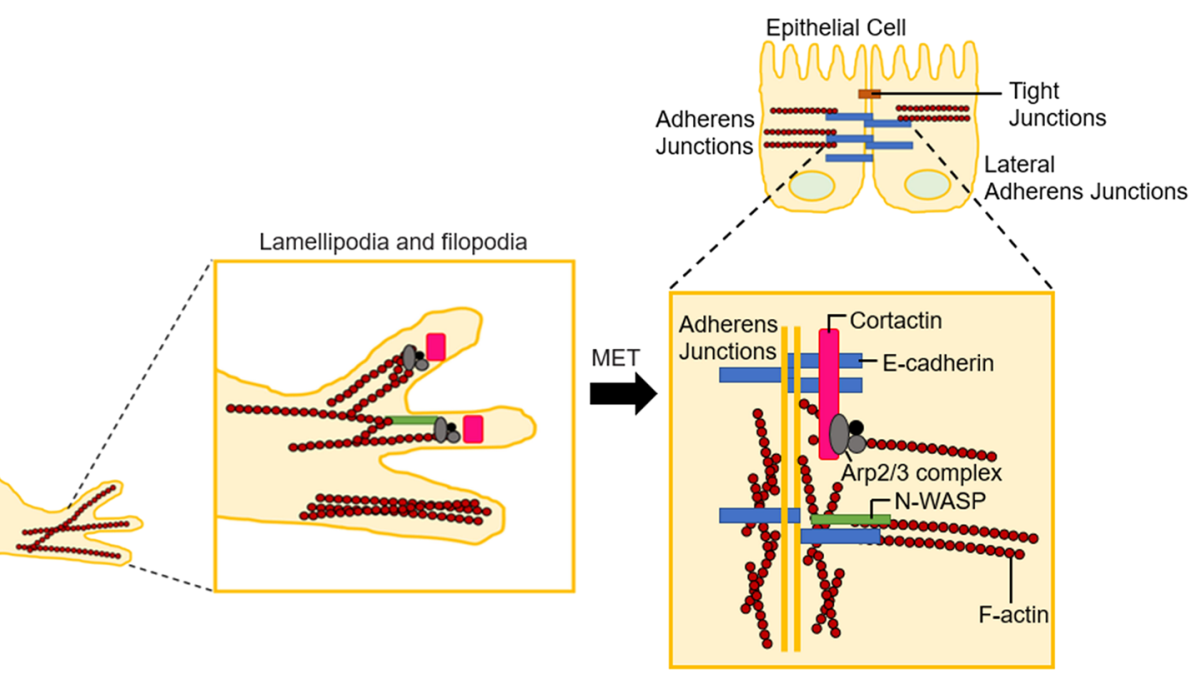

(b)

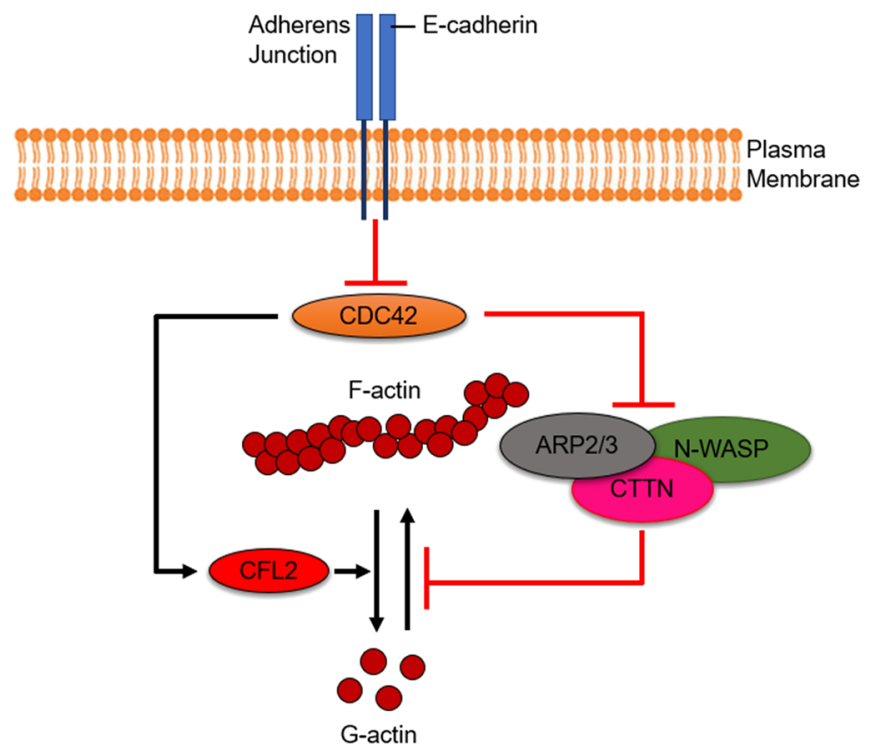

Figure 8. (a) In mesenchymal cells, E-cadherin is not present, and the actin cytoskeleton undergoes several changes, leading to a shift of actin and its regulatory proteins and complexes such as N-WASP, cortactin, and Arp2/3 complex from the cortex towards the leading edge to form lamellipodia. In contrast, epithelial cells form tight junctions to create an intracellular barrier separating the tissue from the outside world and adherens junction between adjacent cells that bestow mechanical stability by connecting with the actin cytoskeleton and E-cadherin. Furthermore, E-cadherin maintains adherens junction integrity by providing a basis for sequestration of actin nucleation proteins in non-motile cells. Cortactin, a scaffolding protein, binds to both N-WASP and E-cadherin to recruit Arp2/3 complex to adherens junctions, leading to a reduction in the expression of actin-regulatory proteins. (b) E-cadherin inhibits CDC42, a small GTPase of the Rho family, which in turn prevents actin interacting regulatory proteins (N-WASP, ARP2/3, and CTTN) from taking part in actin nucleation, at the same time stimulating the activity of actin severing protein CFL2, thereby promoting depolymerization of actin.

of MCF-7 cells compared to MM 231 cells were observed and reported earlier with as-received cells in a study conducted using AFM $^{19}$.

The bone scaffolds-derived MCF-7 cells appear softer and have a larger loss tangent (a measure of liquid-like behavior) than as-received MCF-7 cells (Figs. 2 and 4e). In contrast, elastic moduli and loss tangent values are similar for as-received and scaffolds-derived MM 231 cells (Figs. 3 and 4f). Earlier studies show that dysregulation in actin cytoskeletal dynamics is associated with increased liquidity or liquid-like behavior (represented by higher loss tangent). At the same time, elastic moduli increase with the stabilization of the F-actin network ${ }^{89}$. As received MCF-7 and MDA-MB231 cell lines have been previously investigated for their loss tangents ${ }^{40}$ and more fluid like characteristics of MCF-7 as compared to as recieved MDA-MB-231 cell line is reported. Clearly, on arrival at the bone metastasis location, MCF-7 continues to have increased liquid like behavior while the MDA-MB-231 cells do not exhibit reduction in elastic modulus or liquid-like behavior over time. The inherently 
higher metastatic potential of MDA-MB-231 cells as compared to the MCF-7 cells manifests as largely different changes to mechanics at the bone site.

Actin cytoskeleton dynamics has been shown to play a critical role during transitions between mesenchymal and epithelial states. E-cadherin is not present in the mesenchymal state, and the actin cytoskeleton undergoes several changes, leading to a shift of actin and its regulatory proteins and complexes such as N-WASP, cortactin, and Arp $2 / 3$ complex from the cortex towards the leading edge to form lamellipodia ${ }^{14}$. In contrast, epithelial cells form tight junctions to create an intracellular barrier separating the tissue from the outside world and adherens junction between adjacent cells that bestow mechanical stability by connecting with the actin cytoskeleton and E-cadherin. Furthermore, E-cadherin maintains adherens junction integrity by providing a basis for sequestration of actin nucleation proteins in non-motile cells. Cortactin, a scaffolding protein, binds to both N-WASP and E-cadherin to recruit Arp2/3 complex to adherens junctions ${ }^{14,71}$. Although the Rho family small GTPase CDC42 has been shown to regulate most of the changes in the mesenchymal state ${ }^{90}$, overexpression of E-cadherin (in the epithelial state) has been associated with inhibition of CDC42 $2^{69,91}$. Thus, the degree of F-actin reduction is closely related to the expression of E-cadherin. We have previously reported an enhanced expression of E-cadherin in bone-site breast cancer cells during $\mathrm{MET}^{77}$. This prompted us to calculate the log2 ratios of E-cadherin expression in scaffolds-grown MM 231/MCF-7 compared to their respective controls (Figure S3). We observed a 95.44\% increase in E-cadherin expression in scaffolds-grown MCF-7 cells compared to scaffolds-grown MM 231 cells (Figure S3c). Hence, overexpression of E-cadherin inhibits CDC42, a small GTPase of the Rho family, which in turn prevents actin interacting regulatory proteins (N-WASP, ARP2/3, and CTTN) from participating in actin nucleation, at the same time stimulating the activity of actin severing protein CFL2, thereby promoting depolymerization of F-actin (Fig. 8b). This explains the significant reduction of F-actin in scaffolds-grown MCF-7 cells compared to scaffolds-grown MM 231 cells. In summary, we investigated mechanical properties of as received and 3D bone-mimetic scaffolds-derived breast cancer cells (MCF-7 and MM 231). We found that bone-mimetic scaffolds-derived MCF-7 cells exhibited dramatic changes in elastic modulus and demonstrated liquid-like behavior over time compared to MCF-7 as received cells. In contrast, the bone site or scaffolds-derived MM 231 cells neither showed significant differences in elastic modulus nor exhibited liquid-like behavior over time compared to as received MM 231 cells. The bone site or scaffolds-derived MCF-7 cells were softer and had a larger loss tangent (a measure of liquid-like behavior) than as received MCF-7 cells, whereas while elastic moduli and loss tangent values were similar for as received and scaffolds-derived MM 231 cells. From immunofluorescence and gene expression analysis results, we observed that the significant reduction in elastic modulus together with increased liquid-like behavior of scaffolds-derived MCF-7 cells compared to MCF-7 as received cells, was induced by depolymerization and reorganization of F-actin to the adherens junctions. In contrast, scaffoldsgrown MM 231 cells showed insignificant changes in F-actin reorganization over time, as opposed to their as received counterparts. The significant reduction of F-actin in MCF-7 cells during progression of metastasis at bone site indicates an increased role of the highly viscoelastic cytoplasm in MCF-7, leading to overall increase in loss tangent. MM-231 cells do not exhibit this behavior. Recent studies also demonstrate the relationship between the cell stiffness and energy metabolism in breast cancer cells showing difference in mechanisms of stiffness in healthy cells as compared to metastatic cells ${ }^{40}$. It is interesting to also note that the pathogenesis of the two cell cells is quite different clinically and here we demonstrate the use of a bone scaffold testbed to create metastasis that can be captured through cell mechanics. Collectively, our results showed evolution of breast cancer cell mechanics at bone metastases.

\section{Methods}

Materials, cell lines, and cell culture maintenance. Na-MMT clay was procured from Clay Minerals Respiratory at the University of Missouri. Calcium chloride $\left(\mathrm{CaCl}_{2}\right)$, polycaprolactone (PCL) (average Mn 80,000), 1,4-dioxane, sodium phosphate $\left(\mathrm{Na}_{2} \mathrm{HPO}_{4}\right)$, Tween20, 4',6-diamidino-2-phenylindole (DAPI), fish skin gelatin (FSG), 5-aminovaleric acid, and TritonX-100 were purchased from Sigma Aldrich. Human mesenchymal stem cells (MSCs) (PT-2501) were purchased from Lonza (Walkersville, MD) and maintained in complete growth medium (MSCGM SingleQuots (PT-4105) was added to MSC basal medium (MSCBM, PT-3238) to obtain complete growth medium). Human breast cancer cell lines MCF-7 (HTB-22), MDA-MB-231 (HTB-26) (shortened as MM 231), Eagle's Minimum Essential Medium (EMEM), and Fetal Bovine Serum (FBS) were purchased from American Type Culture Collection (ATCC). Corning Phosphate Buffered Saline (PBS), Hyclone Dulbecco's Modified Eagle medium Nutrient Mixture F-12 DMEM-F-12(1:1), and Alfa Aesar Paraformaldehyde, $4 \%$ in PBS (PFA) were purchased from VWR. Rhodamine Phalloidin, Gibco human recombinant insulin, Gibco penicillin-streptomycin antibiotic solution (P/S), Applied Biosystems Fast SYBR Green, and Gibco TrypLE Express Enzyme (1X), phenol red were purchased from Invitrogen. MCF-7 cells were maintained in EMEM, 10\% FBS, $0.01 \mathrm{mg} / \mathrm{ml}$ human recombinant insulin, and 1\% P/S whereas MM 231 cells were cultured in DMEM-F-12(1:1), 10\% FBS, and $1 \% \mathrm{P} / \mathrm{S}$. All cell cultures were maintained at $37^{\circ} \mathrm{C}$ and $5 \% \mathrm{CO}_{2}$ in a humidified incubator. Direct-zol RNA MiniPrep kit (Zymo Research), anti- $\alpha$-tubulin (Abcam) primary antibody, secondary antibody, and other reagents used were of analytical grade.

Preparation of PCL/in situ HAPclay 3D scaffolds. PCL/in situ HAPclay scaffolds were synthesized following the procedure described elsewhere ${ }^{79}$. Briefly, we modified clay with 5 -aminovaleric acid to increase the d-spacing of clay followed by biomineralization of hydroxyapatite (HAP) into intercalated nanoclay galleries to obtain in situ HAPclay according to the procedure reported in our previous studies ${ }^{92,93}$. Next, $10 \%$ in situ HAPclay was added to the PCL solution to get a composite mixture, which was further subjected to freeze-extraction to synthesize PCL/in situ HAPclay scaffolds. Scaffolds were cut into a cylindrical shape $(\sim 12 \mathrm{~mm}$ diameter and $\sim 3 \mathrm{~mm}$ thickness), sterilized under UV light for $45 \mathrm{~min}$, submerged in $70 \%$ ethanol for $12 \mathrm{~h}$, washed in 
PBS to remove excess ethanol, and stored in a $5 \% \mathrm{CO}_{2}$ incubator at $37^{\circ} \mathrm{C}$ immersed in 24 -well plates containing culture medium for $24 \mathrm{~h}$ before cell seeding.

Cell culture. MSCs were seeded at a density of $5 \times 10^{4}$ cells per scaffold and cultured for 23 days to deposit bone-like extracellular matrix (ECM) onto scaffolds. Then, scaffolds with newly formed bone were seeded with $5 \times 10^{4}$ breast cancer cells (MCF-7/ MM231) per scaffold and maintained in 1:1 MSCs and breast cancer cell medium. Breast cancer cells (MCF-7/MM 231) cultured on 2D tissue culture polystyrene (TCPS) are called "asreceived" throughout the study.

Cellular morphology. Cell-seeded scaffold constructs were fixed with $2.5 \%$ glutaraldehyde overnight, followed by dehydration in a graded series of ethanol solution $(10 \%, 30 \%, 50 \%, 70 \%$, and $100 \%)$ and drying in hexamethyldisilazane. Then, samples were gold sputter coated and observed with a JSM-6490LV SEM (JEOL, Tokyo, Japan).

Quasi-static nanoindentation. The quasi-static mechanical characterization of live breast cancer cells (MCF-7/MM 231) was conducted using TRIBOSCOPE, (Hysitron, Minneapolis, MN) equipped with multimode AFM (Nanoscope IIIa controller and J-type piezo scanner system) (Veeco Metrology, Santa Barbara, $\mathrm{CA}$ ) and a Berkovich diamond indenter fluid tip (three-sided pyramidal; 100-200 nm tip radius) on displacement-controlled mode at maximum displacements of $1000 \mathrm{~nm}$ and $2000 \mathrm{~nm}$ corresponding to contact areas of $2.52 \times 10^{7} \mathrm{~nm}^{2}$ and $9.98 \times 10^{7} \mathrm{~nm}^{2}$ at a loading and unloading rate of $100 \mathrm{~nm} / \mathrm{s}$ based on the area function equation for the Berkovich tip. The area function ${ }^{94}$ used for the berkovich tip is

$$
A=24.675 h_{c}^{2}+0.562 h_{c}+0.003216
$$

where $h_{c}$ is the penetration in $\mathrm{mm}$ and area $\mathrm{A}$ is in $\mathrm{mm}^{2}$. The breast cancer cells were cultured on TCPS and then glued the TCPS with cells onto a 3D-printed holder $(\sim 12 \mathrm{~mm}$ diameter and $\sim 3 \mathrm{~mm}$ height $)$ that was filled with fresh culture medium (EMEM + 2\% FBS (MCF-7), DMEM-F12 + 2\% FBS (MM 231)), which was further glued to a steel disc. The holder containing the cell-seeded TCPS sample was placed onto the nanoindentation stage. The whole assembly was maintained at $37^{\circ} \mathrm{C}$ using a MULTIMODE low-temperature heater from Veeco Metrology (Santa Barbara, CA) during the experiment. All the indentation tests were completed within two hours. For cells grown on 3D scaffolds, cells were extracted using TrypLE Express Enzyme and seeded onto TCPS before performing nanoindentation tests. Nanoindentation was done on such extracted tumors and not on individual cells. Damage to the cell resulting in puncture would drastically reduced the cell's elastic modulus because of the collapse of the cell's internal structure. We did not observe this behavior. In addition, if the cell punctures, no recovery of deformation would be observed. The force-displacement curves during unloading show significant recovery indicating that cells have remained intact during the process of loading and unloading. Using the Oliver \& Pharr method $^{83}$, the elastic modulus $(E)$ of cells was calculated from load-displacement (L-D) curves. In this method, the initial unloading portion of the L-D curve is fitted to power-law function followed by differentiation of power-law relation to obtain contact stiffness. The reduced elastic modulus $\left(E_{r}\right)$ of cancer cells was calculated from the stiffness and contact area. Elastic modulus $(E)$ of cells was further determined from the reduced modulus $\left(E_{r}\right)$, and Poisson's ratio $(v)$ of 0.50 was used for biological systems using the following equation:

$$
\frac{1}{E_{r}}=\frac{\left(1-v^{2}\right)}{E}+\frac{\left(1-v_{i}^{2}\right)}{E_{i}}
$$

where $v$ and $E$ are Poisson's ratio and the elastic modulus of the sample, respectively; and $v_{i}$ and $E_{i}$ are respective properties of the indenter. For diamond, $v_{i}=0.07$ and $E_{i}=1141 \mathrm{GPa}$. For each measured sample, at least 20 cells were measured. Data are reported as a mean \pm standard deviation (SD).

Dynamic nanoindentation. The dynamic mechanical response of live cancer cells was obtained using frequency sweep mode of nano-DMA module on TRIBOSCOPE, (Hysitron, Minneapolis USA) equipped with multimode AFM (NANOSCOPE IIIa controller and J-type piezo scanner system) (Veeco Metrology, Santa Barbara, CA). In this mode, the oscillating dynamic load of $1 \mu \mathrm{N}$ was superimposed on a quasi-static load of 1000 $\mu \mathrm{N}$ over a frequency range of $10-250 \mathrm{~Hz}$. The dynamic nanoindentation tests were performed using the same setup and Berkovich diamond indenter, as described in previous section.

In dynamic nanoindentation tests, the displacement amplitude, load amplitude, and phase lag were measured to calculate the storage modulus $\left(E^{\prime}\right)$, loss modulus $\left(E^{\prime \prime}\right)$, and loss tangent $(\tan \delta)$ of cancer cells. During dynamic nanoindentation tests, the sample is subjected to a small oscillatory load $(P)$ with a known load amplitude $\left(P_{0}\right)$ and frequency $(\omega)$. The alternating displacement response is measured at the same testing frequency during the test using a lock-in amplifier. The sinusoidal behavior of the load $(P)$ and the resulting displacement $\left(X_{0}\right)$ is related to the following expression:

$$
\begin{aligned}
& P=P_{0}+\sin \omega t \\
& X=X_{0}+\sin (\omega t-\varphi)
\end{aligned}
$$

where $t$ is the time, and $\varphi$ is the phase difference between load amplitude $\left(P_{0}\right)$ and displacement amplitude $\left(X_{0}\right)$, respectively. In a dynamic nanoindentation test, the observed response (i.e., the damping coefficient and the stiffness) is the aggregate response of the instrument and the sample being tested. Therefore, the response of the instrument must be subtracted from the aggregate response to obtain the true dynamic properties of the sample. 
Hence, the stiffness $\left(k_{i}\right)$, damping coefficient $\left(C_{i}\right)$, and mass $(m)$ of the indenter are obtained by air calibration before the experiment, followed by real-time correction of the aggregate response for the response of the instrument. Storage modulus $\left(E^{\prime}\right)$ is given by the in-phase elastic response of the sample, and loss modulus $\left(E^{\prime \prime}\right)$ is a measure of the viscoelastic response of the sample/energy being dissipated during the test. The storage modulus $\left(E^{\prime}\right)$, loss modulus $\left(E^{\prime \prime}\right)$, and loss tangent $(\tan \delta)$ are determined by the following expressions:

$$
\begin{aligned}
E^{\prime} & =\frac{k \sqrt{\pi}}{2 \sqrt{A_{c}}} \\
E^{\prime \prime} & =\frac{\omega C \sqrt{\pi}}{2 \sqrt{A_{c}}} \\
\tan \delta & =\frac{E^{\prime \prime}}{E^{\prime}}=\frac{\omega C}{k}
\end{aligned}
$$

where $C$ and $k$ are the damping coefficient and the stiffness of the sample, respectively, and $A_{c}$ is the projected contact area of indenter on the surface of the sample. For each measured sample, at least 20 cells were measured. Data are reported as mean \pm SD.

Gene expression studies. First, the total RNA was extracted from cell-seeded scaffolds and 2D cultures using the Direct-zol RNA MiniPrep kit followed by reverse-transcription of the extracted RNA to synthesize cDNA using random primers, M-MLV reverse transcriptase (Promega) on a thermal cycler (Applied Biosystems). Next, we performed real-time polymerase chain reaction was using cDNA, SYBR Green dye, forward primer, reverse primer on a 7500 Fast Real-Time System (Applied Biosystems). The thermal profile used for the run was comprised of a holding stage $\left(2 \mathrm{~min}\right.$ at $50^{\circ} \mathrm{C}, 10 \mathrm{~min}$ at $\left.95^{\circ} \mathrm{C}\right)$ and a cycling stage $(40$ cycles of $15 \mathrm{~s}$ at $95^{\circ} \mathrm{C}$, and $1 \mathrm{~min}$ at $60^{\circ} \mathrm{C}$ ). The mRNA expression of Neural-Wiskott-Aldrich syndrome protein (N-WASP), cell division control protein 42 homolog (CDC42), ARP2, ARP3, cortactin (CTTN), E-cadherin (CDH1), and cofilin-2 (CFL2) were quantified and normalized to housekeeping gene glyceraldehyde-3-phosphate-dehydrogenase (GAPDH). The relative expression of mRNAs was determined using the comparative $C_{t}$ method $\left(2^{-\Delta \Delta C t}\right)$. Table S1 lists the sequence of primers used. All the experiments were repeated on triplicate samples.

Immunofluorescence staining. Cells grown on scaffolds and $2 \mathrm{D}$ cultures were fixed with paraformaldehyde, 4\% in PBS for 30 min, permeabilized with TritonX-100, 0.2\% in PBS for 5 min, and blocked with FSG, $0.2 \%$ in PBS for $45 \mathrm{~min}$. The samples were then incubated overnight at $4{ }^{\circ} \mathrm{C}$ with primary antibody diluted in a blocking buffer $(0.2 \%$ FSG in PBS containing $0.02 \%$ Tween 20$)$ at a dilution of 1:150. Next, the samples were incubated with Alexa Flour 488 conjugated secondary antibody corresponding to the origin of the primary antibody used for $45 \mathrm{~min}$ at $25^{\circ} \mathrm{C}$. The actin cytoskeleton and Nuclei were stained with Rhodamine Phalloidin and DAPI, respectively. The stained samples were observed under Zeiss AxioObserver.Z1 LSM 700. Images were processed with ImageJ software and the quantitative analysis of both F-actin and $\alpha$-tubulin fluorescence was performed on at least 5-6 cells for each sample evaluated by calculating the corrected total cell fluorescence (CTCF) of each signal as follows:

$\mathrm{CTCF}=$ Integrated density of selected cell $-($ Area of selected cell $\times$ Mean fluorescence of background $)$.

Statistical analysis. Data are reported as mean \pm SD. Statistical significance (p-value) among multiple comparisons was determined using one-way ANOVA followed by the post hoc Tukey test, whereas Student's unpaired $t$-test was used to determine statistical significance (p-value) between two groups, using GraphPad Prism v7.04. $p<0.05$ was considered statistically significant.

Received: 26 October 2020; Accepted: 20 January 2021

Published online: 04 February 2021

\section{References}

1. Yallapu, M. M. et al. The roles of cellular nanomechanics in cancer. Med. Res. Rev. 35, 198-223 (2015).

2. Katti, D. R., Katti, K. S., Molla, S. \& Kar, S. in Encyclopedia of Biomedical Engineering Vol. 1 (ed Roger Narayan) 1-21 (Elsevier, Amsterdam, 2019).

3. Suresh, S. Biomechanics and biophysics of cancer cells. Acta Biomater. 3, 413-438 (2007).

4. Coughlin, M. F. et al. Cytoskeletal stiffness, friction, and fluidity of cancer cell lines with different metastatic potential. Clin. Exp. Metas. 30, 237-250 (2013).

5. Swaminathan, V. et al. Mechanical stiffness grades metastatic potential in patient tumor cells and in cancer cell lines. Can. Res. 71, 5075-5080. https://doi.org/10.1158/0008-5472.can-11-0247 (2011).

6. Faria, E. C. et al. Measurement of elastic properties of prostate cancer cells using AFM. Analyst 133, 1498-1500. https://doi. org/10.1039/b803355b (2008).

7. Li, Q. S., Lee, G. Y. H., Ong, C. N. \& Lim, C. T. AFM indentation study of breast cancer cells. Biochem. Biophys. Res. Commun. 374, 609-613. https://doi.org/10.1016/j.bbrc.2008.07.078 (2008).

8. Lekka, M. et al. Elasticity of normal and cancerous human bladder cells studied by scanning force microscopy. Eur. Biophys. J. Biophys. Lett. 28, 312-316. https://doi.org/10.1007/s002490050213 (1999). 
9. Hu, J., Zhou, Y., Obayemi, J. D., Du, J. \& Soboyejo, W. O. An investigation of the viscoelastic properties and the actin cytoskeletal structure of triple negative breast cancer cells. J. Mech. Behav. Biomed. Mater. 86, 1-13 (2018).

10. Cross, S. E., Jin, Y.-S., Rao, J. \& Gimzewski, J. K. Nanomechanical analysis of cells from cancer patients. Nat. Nanotechnol. 2, 780-783 (2007).

11. Cross, S. E. et al. AFM-based analysis of human metastatic cancer cells. Nanotechnology 19, 384003 (2008)

12. Rosenbluth, M. J., Lam, W. A. \& Fletcher, D. A. Force microscopy of nonadherent cells: A comparison of leukemia cell deformability. Biophys. J. 90, 2994-3003. https://doi.org/10.1529/biophysj.105.067496 (2006).

13. De Craene, B. \& Berx, G. Regulatory networks defining EMT during cancer initiation and progression. Nat. Rev. Cancer 13, 97-110 (2013).

14. Morris, H. T. \& Machesky, L. M. Actin cytoskeletal control during epithelial to mesenchymal transition: focus on the pancreas and intestinal tract. Br. J. Cancer 112, 613-620 (2015).

15. Olson, M. F. \& Sahai, E. The actin cytoskeleton in cancer cell motility. Clin. Exp. Metas. 26, 273 (2009).

16. Yamaguchi, H. \& Condeelis, J. Regulation of the actin cytoskeleton in cancer cell migration and invasion. Biochimica et Biophysica Acta (BBA)-Mol. Cell Res. 1773, 642-652 (2007).

17. Okegawa, T., Pong, R.-C., Li, Y. \& Hsieh, J.-T. The role of cell adhesion molecule in cancer progression and its application in cancer therapy. Acta Biochim. Pol. 51, 445-457 (2004).

18. Calzado-Martín, A., Encinar, M., Tamayo, J., Calleja, M. \& San Paulo, A. Effect of actin organization on the stiffness of living breast cancer cells revealed by peak-force modulation atomic force microscopy. ACS Nano 10, 3365-3374 (2016).

19. Schierbaum, N., Rheinlaender, J. \& Schäffer, T. E. Viscoelastic properties of normal and cancerous human breast cells are affected differently by contact to adjacent cells. Acta Biomater. 55, 239-248 (2017).

20. Kwon, S., Yang, W., Moon, D. \& Kim, K. S. Comparison of cancer cell elasticity by cell type. J. Cancer 11, 5403-5412 (2020).

21. Xu, W. et al. Cell stiffness is a biomarker of the metastatic potential of ovarian cancer cells. PloS ONE 7 (2012).

22. Ketene, A. N., Schmelz, E. M., Roberts, P. C. \& Agah, M. The effects of cancer progression on the viscoelasticity of ovarian cell cytoskeleton structures. Nanomed.-Nanotechnol. Biol. Med. 8, 93-102. https://doi.org/10.1016/j.nano.2011.05.012 (2012).

23. Nikkhah, M., Strobl, J. S., Schmelz, E. M. \& Agah, M. Evaluation of the influence of growth medium composition on cell elasticity. J. Biomech. 44, 762-766. https://doi.org/10.1016/j.jbiomech.2010.11.002 (2011).

24. Nikkhah, M., Strobl, J. S., De Vita, R. \& Agah, M. The cytoskeletal organization of breast carcinoma and fibroblast cells inside three dimensional (3-D) isotropic silicon microstructures. Biomaterials 31, 4552-4561. https://doi.org/10.1016/j.biomaterials.2010.02.034 (2010).

25. Strobl, J. S., Nikkhah, M. \& Agah, M. Actions of the anti-cancer drug suberoylanilide hydroxamic acid (SAHA) on human breast cancer cytoarchitecture in silicon microstructures. Biomaterials 31, 7043-7050 (2010).

26. Nguyen, N., Shao, Y., Wineman, A., Fu, J. \& Waas, A. Atomic force microscopy indentation and inverse analysis for non-linear viscoelastic identification of breast cancer cells. Math. Biosci. 277, 77-88 (2016).

27. Nematbakhsh, Y., Pang, K. T. \& Lim, C. T. Correlating the viscoelasticity of breast cancer cells with their malignancy. Convergent Sci. Phys. Oncol. 3, 034003 (2017).

28. Efremov, Y. M., Wang, W.-H., Hardy, S. D., Geahlen, R. L. \& Raman, A. Measuring nanoscale viscoelastic parameters of cells directly from AFM force-displacement curves. Sci. Rep. 7, 1-14 (2017).

29. Chim, Y. H. et al. A one-step procedure to probe the viscoelastic properties of cells by Atomic Force Microscopy. Sci. Rep. 8, 1-12 (2018).

30. Lekka, M. et al. Cancer cell detection in tissue sections using AFM. Arch. Biochem. Biophys. 518, 151-156 (2012).

31. Coceano, G. et al. Investigation into local cell mechanics by atomic force microscopy mapping and optical tweezer vertical indentation. Nanotechnology. https://doi.org/10.1088/0957-4484/27/6/065102 (2016).

32. Guo, X., Bonin, K., Scarpinato, K. \& Guthold, M. The effect of neighboring cells on the stiffness of cancerous and non-cancerous human mammary epithelial cells. New J. Phys. 16, 105002 (2014).

33. Staunton, J. R., Doss, B. L., Lindsay, S. \& Ros, R. Correlating confocal microscopy and atomic force indentation reveals metastatic cancer cells stiffen during invasion into collagen I matrices. Sci. Rep. 6 (2016).

34. Nawaz, S. et al. Cell visco-elasticity measured with AFM and optical trapping at sub-micrometer deformations. PloS ONE 7 (2012).

35. Taubenberger, A. V. et al. 3D microenvironment stiffness regulates tumor spheroid growth and mechanics via p21 and ROCK. Advanced Biosystems 3, 16. https://doi.org/10.1002/adbi.201900128 (2019).

36. Molla, M. D. S., Katti, D. R. \& Katti, K. S. Mechanobiological evaluation of prostate cancer metastasis to bone using an in vitro prostate cancer testbed. J. Biomech. 114, 110142. https://doi.org/10.1016/j.jbiomech.2020.110142 (2021).

37. Khanna, R., Katti, K. S. \& Katti, D. R. Experiments in nanomechanical properties of live osteoblast cells and cell-biomaterial interface. J Nanotechnol Eng Med 2, 041005 (Pages 041013) (2012).

38. Rother, J., Noding, H., Mey, I. \& Janshoff, A. Atomic force microscopy-based microrheology reveals significant differences in the viscoelastic response between malign and benign cell lines. Open Biol. 4, 7. https://doi.org/10.1098/rsob.140046 (2014).

39. Efremov, Y. M. et al. Anisotropy vs isotropy in living cell indentation with AFM. Sci. Rep. https://doi.org/10.1038/s41598-019-42077 $-1(2019)$.

40. Yubero, M. et al. Effects of energy metabolism on the mechanical properties of breast cancer cells. Commun. Biol. 3, 9. https://doi. org/10.1038/s42003-020-01330-4 (2020).

41. Zhu, X. et al. Energy metabolism in cancer stem cells. World J. Stem Cells 12, 448-461. https://doi.org/10.4252/wjsc.v12.i6.448 (2020).

42. Schierbaum, N., Rheinlaender, J. \& Schaeffer, T. E. Combined atomic force microscopy (AFM) and traction force microscopy (TFM) reveals a correlation between viscoelastic material properties and contractile prestress of living cells. Soft Matter 15, 1721-1729. https://doi.org/10.1039/c8sm01585f (2019).

43. Efremov, Y. M., Shpichka, A. I., Kotova, S. L. \& Timashev, P. S. Viscoelastic mapping of cells based on fast force volume and PeakForce Tapping. Soft Matter 15, 5455-5463. https://doi.org/10.1039/c9sm00711c (2019).

44. Arfsten, J., Bradtmöller, C., Kampen, I. \& Kwade, A. Compressive testing of single yeast cells in liquid environment using a nanoindentation system. J. Mater. Res. 23, 3153-3160 (2008).

45. Khanna, R., Katti, K. S. \& Katti, D. R. Experiments in nanomechanical properties of live osteoblast cells and cell-biomaterial interface. J. Nanotechnol. Eng. Med. 2, 041005 (2011).

46. Khanna, R., Katti, D. R. \& Katti, K. S. AFM and nanoindentation studies of bone nodules on chitosan-polygalacturonic acidhydroxyapatite nanocomposites. Cmes-Comput. Model. Eng. Sci. 87, 530-555 (2012).

47. Ebenstein, D. M. \& Pruitt, L. A. Nanoindentation of soft hydrated materials for application to vascular tissues. J. Biomed. Mater. Res. A 69, 222-232 (2004).

48. Franke, O., Göken, M., Meyers, M. A., Durst, K. \& Hodge, A. M. Dynamic nanoindentation of articular porcine cartilage. Mater. Sci. Eng., C 31, 789-795 (2011).

49. Roy, M. E., Rho, J. Y., Tsui, T. Y., Evans, N. D. \& Pharr, G. M. Mechanical and morphological variation of the human lumbar vertebral cortical and trabecular bone. J. Biomed. Mater. Res. 44, 191-197 (1999).

50. Katti, K. S., Gu, C. \& Katti, D. R. Anisotropic properties of human cortical bone with osteogenesis imperfecta. Biomech. Model. Mechanobiol. 15, 155-167 (2016). 
51. Gu, C., Katti, D. R. \& Katti, K. S. Dynamic nanomechanical behaviour of healthy and OI human cortical bone. Bioinspired Biomimetic Nanobiomater. 4, 15-25 (2015).

52. Gu, C., Katti, D. R. \& Katti, K. S. Microstructural and photoacoustic infrared spectroscopic studies of human cortical bone with osteogenesis imperfecta. JOM 68, 1116-1127 (2016).

53. Mohanty, B., Katti, K. S., Katti, D. R. \& Verma, D. Dynamic nanomechanical response of nacre. J. Mater. Res. 21, 2045-2051 (2006).

54. Katti, K. S., Mohanty, B. \& Katti, D. R. Nanomechanical properties of nacre. J. Mater. Res. 21, 1237-1242 (2006).

55. Mohanty, B., Katti, K. S. \& Katti, D. R. Experimental investigation of nanomechanics of the mineral-protein interface in nacre. Mech. Res. Commun. 35, 17-23 (2008).

56. Balooch, G. et al. Evaluation of a new modulus mapping technique to investigate microstructural features of human teeth. J. Biomech. 37, 1223-1232 (2004).

57. Kinney, J. H., Marshall, S. J. \& Marshall, G. W. The mechanical properties of human dentin: a critical review and re-evaluation of the dental literature. Crit. Rev. Oral Biol. Med. 14, 13-29 (2003).

58. Yokokawa, M., Takeyasu, K. \& Yoshimura, S. H. Mechanical properties of plasma membrane and nuclear envelope measured by scanning probe microscope. J. Microsc. 232, 82-90. https://doi.org/10.1111/j.1365-2818.2008.02071.x (2008).

59. Barreto, S., Clausen, C. H., Perrault, C. M., Fletcher, D. A. \& Lacroix, D. A multi-structural single cell model of force-induced interactions of cytoskeletal components. Biomaterials 34, 6119-6126. https://doi.org/10.1016/j.biomaterials.2013.04.022 (2013).

60. Subra, S. Biomechanics and biophysics of cancer cells. Acta Biomater. 3, 413-438. https://doi.org/10.1016/j.actbio.2007.04.002 (2007).

61. Gershon, N. D., Porter, K. R. \& Trus, B. L. The cytoplasmic matrix: its volume and surface area and the diffusion of molecules through it. Proc. Natl. Acad. Sci. USA 82, 5030-5034 (1985).

62. Stricker, J., Falzone, T. \& Gardel, M. L. Mechanics of the F-actin cytoskeleton. J. Biomech. 43, 9-14 (2010).

63. Bao, G. \& Suresh, S. Cell and molecular mechanics of biological materials. Nat. Mater. 2, 715-725 (2003).

64. Fletcher, D. A. \& Mullins, R. D. Cell mechanics and the cytoskeleton. Nature 463, 485-492 (2010).

65. Ramos, J. R., Pabijan, J., Garcia, R. \& Lekka, M. The softening of human bladder cancer cells happens at an early stage of the malignancy process. Beilstein J. Nanotechnol. 5, 447-457 (2014).

66. Kalluri, R. \& Weinberg, R. A. The basics of epithelial-mesenchymal transition. J. Clin. Investig. 119, 1420-1428 (2009).

67. Haynes, J., Srivastava, J., Madson, N., Wittmann, T. \& Barber, D. L. Dynamic actin remodeling during epithelial-mesenchymal transition depends on increased moesin expression. Mol. Biol. Cell 22, 4750-4764 (2011).

68. Shankar, J. et al. Pseudopodial actin dynamics control epithelial-mesenchymal transition in metastatic cancer cells. Can. Res. 70, 3780-3790 (2010).

69. Shankar, J. \& Nabi, I. R. Actin cytoskeleton regulation of epithelial mesenchymal transition in metastatic cancer cells. PloS ONE 10 (2015).

70. Le Clainche, C. \& Carlier, M.-F. Regulation of actin assembly associated with protrusion and adhesion in cell migration. Physiol. Rev. 88, 489-513 (2008).

71. Wu, S. K. et al. Cortical F-actin stabilization generates apical-lateral patterns of junctional contractility that integrate cells into epithelia. Nat. Cell Biol. 16, 167-178 (2014).

72. Iwaya, K., Norio, K. \& Mukai, K. Coexpression of Arp2 and WAVE2 predicts poor outcome in invasive breast carcinoma. Mod. Pathol. 20, 339-343 (2007).

73. Otsubo, T. et al. Involvement of Arp2/3 complex in the process of colorectal carcinogenesis. Mod. Pathol. 17, 461-467 (2004).

74. Marturano-Kruik, A. et al. Human bone perivascular niche-on-a-chip for studying metastatic colonization. Proc. Natl. Acad. Sci. 115, 1256-1261 (2018).

75. Nyga, A., Cheema, U. \& Loizidou, M. 3D tumour models: novel in vitro approaches to cancer studies. J. Cell Commun. Signal. 5, 239-248. https://doi.org/10.1007/s12079-011-0132-4 (2011).

76. Kretschmann, K. L. \& Welm, A. L. Mouse models of breast cancer metastasis to bone. Cancer Metastasis Rev. 31, 579-583 (2012).

77. Kar, S., Molla, M. D. S., Katti, D. R. \& Katti, K. S. Tissue-engineered nanoclay-based 3D in vitro breast cancer model for studying breast cancer metastasis to bone. J. Tissue Eng. Regenerat. Med. 13, 119-130 (2019).

78. Molla, S., Katti, D. R. \& Katti, K. S. In vitro design of mesenchymal to epithelial transition of prostate cancer metastasis using 3D nanoclay bone-mimetic scaffolds. J. Tissue Eng. Regenerat. Med. (2017).

79. Ambre, A. H., Katti, D. R. \& Katti, K. S. Biomineralized hydroxyapatite nanoclay composite scaffolds with polycaprolactone for stem cell-based bone tissue engineering. J. Biomed. Mater. Res., Part A 103, 2077-2101 (2015).

80. Katti, K. S., Ambre, A. H., Payne, S. \& Katti, D. R. Vesicular delivery of crystalline calcium minerals to ECM in biomineralized nanoclay composites. Mater. Res. Express 2, 13. https://doi.org/10.1088/2053-1591/2/4/045401 (2015).

81. Kar, S., Jasuja, H., Katti, D. R. \& Katti, K. S. Wnt/beta-catenin signaling pathway regulates osteogenesis for breast cancer bone metastasis: experiments in an in vitro nanoclay scaffold cancer testbed. ACS Biomater. Sci. Eng. 6, 2600-2611. https://doi.org/10.1021/ acsbiomaterials.9b00923 (2020).

82. Kar, S., Katti, D. R. \& Katti, K. S. Bone interface modulates drug resistance in breast cancer bone metastasis . Colloids Surfaces $B$ Biointerfaces 195, 111224-111224. https://doi.org/10.1016/j.colsurfb.2020.111224 (2020).

83. Oliver, W. C. \& Pharr, G. M. An improved technique for determining hardness and elastic modulus using load and displacement sensing indentation experiments. J. Mater. Res. 7, 1564-1583 (1992).

84. Chiou, Y.-W., Lin, H.-K., Tang, M.-J., Lin, H.-H. \& Yeh, M.-L. The influence of physical and physiological cues on atomic force microscopy-based cell stiffness assessment. PloS ONE 8 (2013).

85. Gavara, N. A beginner's guide to atomic force microscopy probing for cell mechanics. Microsc. Res. Tech. 80, 75-84 (2017).

86. Rigato, A., Miyagi, A., Scheuring, S. \& Rico, F. High-frequency microrheology reveals cytoskeleton dynamics in living cells. Nat. Phys. 13, 771-775 (2017).

87. Staunton, J. R., So, W. Y., Paul, C. D. \& Tanner, K. High-frequency microrheology in 3D reveals mismatch between cytoskeletal and extracellular matrix mechanics. Proc. Natl. Acad. Sci. 116, 14448-14455 (2019).

88. Rotsch, C. \& Radmacher, M. Drug-induced changes of cytoskeletal structure and mechanics in fibroblasts: An atomic force microscopy study. Biophys. J. 78, 520-535 (2000).

89. Fabry, B., Klemm, A. H., Kienle, S., Schäffer, T. E. \& Goldmann, W. H. Focal adhesion kinase stabilizes the cytoskeleton. Biophys. J. 101, 2131-2138 (2011).

90. Woodham, E. F. \& Machesky, L. M. Polarised cell migration: intrinsic and extrinsic drivers. Curr. Opin. Cell Biol. 30, 25-32 (2014).

91. Asnaghi, L. et al. E-cadherin negatively regulates neoplastic growth in non-small cell lung cancer: role of Rho GTPases. Oncogene 29, 2760-2771 (2010).

92. Ambre, A., Katti, K. S. \& Katti, D. R. In situ mineralized hydroxyapatite on amino acid modified nanoclays as novel bone biomaterials. Mater. Sci. Eng., C 31, 1017-1029 (2011).

93. Katti, K. S., Ambre, A. H., Peterka, N. \& Katti, D. R. Use of unnatural amino acids for design of novel organomodified clays as components of nanocomposite biomaterials. Philos. Trans. R. Soc. Lond. A: Math. Phys. Eng. Sci. 368, 1963-1980 (2010).

94. Sakharova, N. A., Fernandes, J. V., Antunes, J. M. \& Oliveira, M. C. Comparison between Berkovich, Vickers and conical indentation tests: A three-dimensional numerical simulation study. Int. J. Solids Struct. 46, 1095-1104. https://doi.org/10.1016/j.ijsol str.2008.10.032 (2009). 


\section{Acknowledgments}

This research was supported by funds from NDSU Grand Challenge Initiative for "Center for Engineered Cancer Beds". Support from NSF grant NDACES-1946202 and NIH U54GM128729 is also acknowledged. The authors acknowledge use of instruments in Electron Microscopy Center, Core Biology Facility, and Advanced Imaging \& Microscopy Lab at NDSU. The nanoindentation equipment used in this study was obtained through NSF Instrumentation for Materials Research Grant.

\section{Author contributions}

K.S.K. and D.R.K. conceptualized the project and planned experiments, S.K. conducted the experiments and wrote the first draft and prepared the figures. Many discussions between all authors led to the experimental plan of the project and all authors contributed to the design of the experimental plan. All authors have reviewed the manuscript.

\section{Competing interests}

The authors declare no competing interests.

\section{Additional information}

Supplementary Information The online version contains supplementary material available at https://doi. org/10.1038/s41598-021-82664-9.

Correspondence and requests for materials should be addressed to K.S.K.

Reprints and permissions information is available at www.nature.com/reprints.

Publisher's note Springer Nature remains neutral with regard to jurisdictional claims in published maps and institutional affiliations.

(c) Open Access This article is licensed under a Creative Commons Attribution 4.0 International License, which permits use, sharing, adaptation, distribution and reproduction in any medium or format, as long as you give appropriate credit to the original author(s) and the source, provide a link to the Creative Commons licence, and indicate if changes were made. The images or other third party material in this article are included in the article's Creative Commons licence, unless indicated otherwise in a credit line to the material. If material is not included in the article's Creative Commons licence and your intended use is not permitted by statutory regulation or exceeds the permitted use, you will need to obtain permission directly from the copyright holder. To view a copy of this licence, visit http://creativecommons.org/licenses/by/4.0/.

(C) The Author(s) 2021 